Review of Education

\title{
“Are we there yet?": A multimethod study of the Oxford University Press Pathways to school improvement
}

\begin{abstract}
This article presents one substantive and illustrative school case study to explore in depth practitioners' engagement with Pathways - an online school improvement resource provided by the Oxford University Press (OUP). Launched in 2013, the 'four-step system' comprises the following phases: 'audit', 'strategic planning', 'take action' and 'evaluate impact' and aims to support primary schools through a range of whole school improvement and teaching and learning tasks. The wider research project studied primary school practitioner perceptions and attitudes towards Pathways and both collective and individual improvement practice via an embedded multimethod case study comprising a purposive sample of five primary schools that signed up to use Pathways. It followed the evolution of Pathways using a "designbased research" (DBR) framework which focuses on bridging the realms of academia and more practical contexts, and promoting research impact through user engagement and active participation. The growth and use of Pathways by schools was investigated through the theoretical lenses of the Dynamic Approach to School Improvement, DASI (Creemers and Kyriakides, 2012) and Guskey's five-level model of Continuing Professional Development, CPD evaluation (2002). The Pathways research and case study in this article focus uniquely on how teaching practitioners engage with and perceive technology in their school improvement practice and professional development experiences in one particular school context. Pathways tools seemed to offer opportunities for teachers to work collaboratively, individually and autonomously - with their work being partially 'mediated' by Pathways itself, and specific 'hospitable conditions' cultivated by senior leadership such as professional support and trust.
\end{abstract}




\section{Study overview}

This article focuses on one illustrative school case study that helps to elucidate the wider study which explores the workings of, and practitioner engagement with, Oxford University Press (OUP) Pathways in primary school improvement. In addition to publishing curriculum resources for schools, the OUP has been actively involved in developing materials for teaching practitioners in the areas of school improvement and professional development. In 2013, the OUP launched a "four-step system" to school improvement in the form of Pathways. Each Pathway contains web-based resources such as audit tools, questionnaires and guidance documentation that attempt to support schools through specific activities (or 'issues' as they are termed in Pathways). Examples of such issues include the implementation of the new primary National Curriculum (NC) in England - the majority of which was introduced in September 2014 by the Department for Education in the UK (DfE, 2014), putting measures in place to build an 'outstanding reading school', narrowing the gap, raising boys' achievement and increasing parental engagement.

One core purpose of the wider research was to study and understand school practitioners' perceptions and attitudes towards school improvement and their use of Pathways and other resources to support their practice and professional development. In particular, this qualitative, multimethod exploratory case study investigated and describes the perspectives of headteachers, other members of school senior management and teachers towards the OUP approach to school improvement and Pathways. The specific case study presented in this piece was chosen to illustrate in detail the multimethod, collaborative approach to the study. The research as a whole also studied the evolution of the Pathways themselves and the nature of school improvement practice and links with Pathways resources within a purposive sample of five primary schools. There is a particular focus on diagnosis, capacity-building and leadership with an aim of studying and illuminating the variety of school improvement 'journeys' within individual schools (Hopkins, 1998; Day et. al., 2011; Hallinger and Heck, 2011; Chapman and Sammons, 2013). Each case study in the full write-up uses as a framework Guskey's Five Level Model of Continuous Professional Development (CPD) Evaluation (2002) in investigating how teachers, particularly school leaders, compiled and used different forms of evidence to inform their practice and support collaborative working with their colleagues, using a mixture of resources that may have included Pathways.

\section{Background}

The main stated aim of the OUP, as a department of the University of Oxford, is to support and widen the university's objective of "excellence in research, scholarship, and education" through the means of publishing (OUP, 2016). Historically, the OUP has produced (amongst other resources) materials aimed 
at parents and schools in supporting children's learning. They have also developed resources for teachers and their professional development. The Pathways web-based platform for schools was developed over a period of between 18 to 24 months (from the initial idea or concept of building such a platform up to its official launch) using expert advice and input from an advisory group made up of a variety of consultants, including former headteachers and school senior leaders, two former Ofsted ${ }^{1}$ inspectors, subject specialists, teachers and university academics. On 5 November 2013, Pathways was launched with the first in the series focusing on "managing and implementing the new National Curriculum" (NC) in primary schools. The launch of this first Pathway (which was and continues to be offered to schools free of charge) followed the publication in September 2013 of a new NC framework in England by the Department for Education (DfE). This first Pathway is a resource aimed at supporting schools through the implementation of the programmes of teaching, learning and assessment associated with the new NC. In November 2014, nine other Pathways were launched, access to which is offered to schools via an annual paid subscription of $£ 499$. As of February 2018, the 23 Pathways in total comprise

- ten focusing on "whole school improvement" ("Assessment for Learning” [provided for free until 2017], "Managing and Implementing the National Curriculum” [currently still free], "Assessment without Levels", "Closing the Gap", "Developing Best Practice in the Early Years", "Effective Governance", "Effective Self-Evaluation", "Outstanding SEND and Inclusion Practice", "Parental Engagement" [very recently provided for free] and "Raising Boys" Achievement") and;

- 13 focusing on "teaching and learning" (nine English Pathways: "Building an Outstanding Reading School”, "Developing Early Writing”, “Guided Reading”, “Improving Big Writing Practice”, "Improving Grammar", "Improving Phonics", "Improving Spelling”, "Improving Writing” and "Teaching Comprehension" \& four dedicated to mathematics: "Mastering Mathematics", "Mathematical Reasoning", "Number and Calculation" and "Problem Solving in Mathematics").

All Pathways sit on a wider platform called 'Oxford Owl' which holds a wide range of resources for schools and parents, many of which are free (e.g. e-books and guidance for parents and teachers). Pathways is located in the 'schools' division of Oxford Owl.

A screenshot of the Pathways web platform is shown below in Figure 1 including the phases that make up the "four-step system".

[Figure 1 here]

\footnotetext{
${ }^{1}$ Ofsted is a regulatory body independent of government that carries out inspections of schools and other educational institutions in England. Results of inspections are published online and hold high stakes consequences for schools and communities. Negative inspection results may sometimes result in schools being forced to become 'academies' or closing down. Academies are publicly-funded independent schools that are run by trusts, sometimes sponsored by businesses, universities, other schools, and faith-based or voluntary organisations. Independent schools do not have to follow the National Curriculum and can set their own term times. [Source: https://www.gov.uk/types-of-school/academies]
} 
The self-evaluative approach represented in the 'Overview' and four-step system in Figure 1 aims to provide opportunities for practitioners to assess schools' functioning and pupil outcomes while examining the processes and interactions that played a role in reaching those outcomes.

The wider research investigated, describes and analyses how the OUP steps and Pathways approaches to school improvement are perceived, interpreted and used in five different case study schools across England. In line with how Pathways is structured around the four core steps highlighted above, starting with an initial audit of current practices and finishing with a self-evaluation of new practices, one key learning point that has emerged from previous school improvement research is that "a clear and practical focus for development is linked to simultaneous work on the internal conditions within the school" (Reynolds, Hopkins and Stoll, 1993: 46). The final evaluative phase would ideally involve a collective search for meanings and clarity, a period of system refinement and activities that allow practitioners to monitor progress and enhance their professional judgement (Ainscow and Hopkins, 1992). Different types of knowledge and how understandings seemed to have been constructed were explored, as illustrated in the substantive case study.

The illustrative case study of Magpie School highlighted in this article focuses on exploring practitioner engagement with OUP Pathways and other resources for school improvement, studying individual school improvement practice and more peripherally, on how practitioners' experiences may have featured in the design/redesign cycle of Pathways by OUP. This article focuses only on the first two research objectives of the fuller DPhil study which are:

1. Gathering views and perceptions from staff and other stakeholders in schools and OUP on Pathways development and use in schools; and

2. Mapping schools' improvement journeys, how they might (or might not) link with Pathways approaches and resources and the interactions among teachers and senior management using as lenses two frameworks: Dynamic Approach to School Improvement or DASI (Creemers and Kyriakides, 2012) and Guskey's alternative model of teacher change (2002), specifically exploring the extent to which Pathways is perceived to support the development of collaborative inquiry, professional practice and improved pupil outcomes in schools.

The featured case study of Magpie School (one of the five in-depth case studies of schools that engaged with Pathways) attempts to illustrate the main aspects of the DBR and multimethod approach applied in the project. As such, the two research questions (out of the wider three) that are addressed are: RQ1. What are the views and perceptions of practitioners in their use of Pathways around the functionality of the platform and its tools?

RQ2. What role does practitioners' use of Pathways (and other related resources) play in supporting individual schools' improvement journeys and approaches and practitioners' professional development experiences? 
A brief review of the literature is presented next which condenses the three main fields underpinning this study: school improvement, school effectiveness and the design-based research approach.

\section{Context: School improvement and DASI}

The two main fields of research that inform the wider Pathways study are that of school improvement and school effectiveness. The concomitant subtopics that will be discussed here in brief include knowledge management systems, organisational learning, practitioners' (online) continuous professional development, and the DASI.

\section{School improvement (SI)}

School improvement has been recognised as:

- A series of overlapping processes that take place within a collective endeavour that can "significantly enhance the quality of teaching and learning" (Harris, 2002: 5)

- Strategies that encompass valuable lessons and signposts that schools can access in order to construct their own facilities and capacities for improvement (Harris, 2002)

- (Running parallel with classroom practice) a means of developing a professional learning community in which teachers and students learn and progress together.

Combining these characteristics, school improvement has also been framed as:

[A] distinct approach to educational change that enhances student outcomes as well as strengthening the school's capacity for managing change. (Hopkins, Ainscow and West, 1994: 261)

In practical terms, improvement-type processes have often been observed to propagate or 'fire-up' following a 'spark' such as an evaluation or observation of a school's particular functions or ways of working (Harris, Jamieson and Russ, 1996; Matthews and Sammons, 2004; 2005). On the whole, school improvement can be seen as a path of growth or maturation over time that is dynamic in nature and responsive to internal and external stimuli (Mortimore and MacBeath, 2003); it has in fact been described in 'horticultural' terms, involving periods of:

- The "sowing" or generation of ideas in a school culture that enables such endeavours;

- the "germinating" or careful cultivation of these ideas;

- the selection or "thinning" of the most promising projects;

- the "pruning" process where knowledge is shaped and validated; and 
- the disseminating and exchange of knowledge or what we would term, 'propagation', after which the growth process may continue into a different series of processes and initiatives. (Hargreaves, 1998: 29-32)

This framework, although useful, misses one crucial element which is that of self-evaluation; which when carried out effectively (i.e. evaluatively as opposed to descriptively), could aid the propagation phase to work more efficiently (Bubb et al, 2007; Reed and Street, 2002). The original notion of schools and ideas as 'living organisms', however, is an attractive metaphor. It serves its purpose in encouraging researchers and practitioners to consider educational institutions as evolving structures and settings where strategies are being tested and applied in vivo, and hence require due care and attention in the event that they 'fall ill' and become weak. More sophisticated models of school improvement such as the "dynamic model of educational effectiveness" (Creemers and Kyriakides, 2008) seek to forge stronger ties between Educational Effectiveness Research (EER) and improvement practices (Creemers and Kyriakides, 2015). The metaphor of the 'living' or developing organisation is extended in a more practical sense with the Dynamic Approach to School Improvement or DASI (Creemers and Kyriakides, 2012), which by the authors' account, provides schools and practitioners with more than just a model of the different factors that are associated with learning outcomes (Creemers and Kyriakides, 2010a). The DASI, supported by a series of empirical evidence testing the validity of the dynamic model (e.g. Creemers and Kyriakides, 2009; 2010b):

stresses the importance of collecting data about the functioning of factors at the classroom and school level to identify teacher and school improvement needs, respectively. In this way, an evidence-based and theory-driven approach to improvement can be gradually developed. (Creemers and Kyriakides, 2015: 105)

Each factor in the dynamic model is defined along five dimensions, where frequency measures quantitatively the "functioning" of that factor, and focus, stage, quality and differentiation qualitatively measure functioning of effectiveness at a classroom / school / system level (Creemers and Kyriakides, 2015). This links closely with the "reframing" - Silins and Mulford (2002) remark - of schools as learning organisations; or indeed where Louis, Toole and Hargreaves (1999) found in their particular study, as organisations where the examination of and learning from past practices seemed less supported and even uncertain. The word limit of this piece permits only a brief tour through the concept of Organisational Learning (OL), or the "detection and correction of error" as put forward by Argyris and Schön (1978). One component that has been linked with OL is that of Knowledge Management (KM) systems which, often associated with information technology but not always, can be seen as a means of supporting continuous organisational learning (Spector and Edmonds, 2002) and providing the 'feedback loop' necessary for schools to build and sustain their capacity for change (Bain and Swan, 2011). KM systems can take the form of mechanisms to for example, formulate strategic plans and curriculum goals or store and analyse student attainment data. In the context of Pathways, the potential for such a platform to support the collection of audit, feedback and evaluation data at different points and from different 
sources presents the opportunity for this study to ask: what is it that Pathways is designed to achieve and why and how is the application of the design used in schools, each in their unique but shared contexts as primary level educational institutions and seeking to 'improve' in some way? Certainly as Bain and Swan (2011: 676) are not alone in pointing out, "moving from intention to application is always a difficult transition". They go on to discuss ideas around the design of feedback tools to enable school improvement; the three stages of which they categorise as "Solution Mapping, Component Building, and Design Integration" (Bain and Swan, 2011: 677). Each stage is represented on the left of Figure 2 below, along with a brief description of each stage on the right, along with how this framework links with this study.

[Figure 2 here]

The Pathways research sought to study a combination of the three different stages highlighted in Figure 2 , particularly during stages 2 and 3 where the DBR methodology will be used to observe, participate in and understand how Pathways is being designed and redesigned, and continues to 'develop' or evolve, in the context of the OUP itself and against the backdrop of schools' own development or change journeys. Research literature on practitioners' use of online technologies for the purposes of school improvement is scant. Blau and Presser (2013) detail the different e-communication flows of secondary school principals in the Israeli context using "school management systems" and tools for "data-based decision making" while Leask and Younie (2013) discuss the dearth of research into teachers' continuous professional development (CPD) in the context of digital technologies. In an era of growing interest in the use of online technology to aid various aspects of education including e-resources for pupils and parents, it seems fitting to also explore how teachers go about using technology in their school improvement practice. My study aims to develop some understanding in this area:

The component building process can result in dozens of forms, screens and tools that reflect both content areas of interest (pedagogy, collaboration and adaptation of content) and the feedback requirements (multiple sources and methods). This detail is then employed in the design integration stage to build a technological solution that involves using the software interface to provide the "glue" for connecting the components. This is especially important in addressing the timing of feedback and form in which it is reported. (Bain and Swan, 2011: 679)

Of course, the stages in reality are unlikely to progress in a linear or even circular fashion. Commenting on the rather worrying revelations from research by Argyris and Schön (1978: 39-40) which uncovered the limits to organisational learning, such as letting "buried failures lie" and avoiding the 'surfacing' or testing of opposing views in organisational conflict, Scheerens (2015:19) warns of what may lie beneath the "less contested" areas of school self-evaluation: "resistance, immunization against potential criticism, and barriers to organizational learning". Creemers and Kyriakides (2012: 165-166) meanwhile stress the importance of school stakeholder buy-in to any school improvement project: 
It is important to acknowledge that each member of the school may have his/her own views on what the priorities for improvement are. However, after the results of the [School Self Evaluation] have identified a priority area for improvement all stakeholders are expected to show a willingness to work on this area.

The multimethod approach lends itself well to how the Pathways study also used the DBR approach which calls for a degree of flexibility in the data collection phase. Luyten, Visscher and Witziers (2005: 271) recommend that SER should focus less on the "well-known key variables" and instead try to draw more on theory to help "explain specific phenomena" that can also adapt to individual school settings and contexts. They give an example around "organisational functioning" and how the development of theories in this area might be useful:

[T] he concept of "the learning organisation" implies a causal chain; the sustainability of an organisation relies on innovation and improvement that, in turn, can be attained only by unlocking individual potential and enhancing commitment by creating favourable organisational conditions. (Luyten, Visscher and Witziers, 2005: 271-272)

The current study aims to examine organisational functions and processes of working that:

- translate from primary school leadership, senior management roles, middle management and other teaching practitioners and move into the classroom

○ via the channels of online technology (Pathways) and its resources

- against the backdrop of schools' improvement plans, strategies, practice and evaluation.

No publicly available research was found related to the particular combination of factors and contexts highlighted above. Indeed, the study also aims to develop tentative theoretical formulations that may aid, for example, with questions such as:

... why and how the school context interacts with school performance and with processes at both the classroom and the school level. For example, the conditions under which contextual characteristics match with features of classroom and school processes and why represent an important area for further investigation. (Luytens, Visscher and Witziers, 2005: 259)

So, to what ends were Pathways resources being designed and for what purpose? Here it is important to consider the area of school effectiveness and how effectiveness and improvement processes can be linked, particularly in the context of the DASI.

The very concept of educational effectiveness ${ }^{2}$ is based on the rational idea of optimal goal attainment. The factors "that work" can be seen as effective means to reach educational goals. (Scheerens, 2015: 17)

\footnotetext{
${ }^{2}$ The term educational effectiveness or more specifically Educational Effectiveness Research (EER) is increasingly being used more widely than school effectiveness or School Effectiveness Research (SER) (Sammons, 2012; Creemers et al, 2010; Muijs, 2006). EER recognises the broader scope of more recent research into effectiveness of educational institutions, including the role of local authorities, school districts and pre-schools (Sammons, 2012) plus Teacher Effectiveness Research (TER) and School/System Improvement Research (SSIR) (Harris et al, 2013). However, as this study focuses on primary schools as 'units of analysis', the usage of 'school
} 
In studying schools' real-life 'worlds' and sometimes messy contexts which are subject to various internal and external pressures, rationality might not be the most appropriate way to study improvement. Hence the multimethod, DBR approach was used, and one unique case study is highlighted here, that seeks to illuminate and understand the ways that practitioners used Pathways for their chosen purposes of development and professional learning.

\section{School effectiveness (SE)}

School effectiveness is understood to be primarily based around investigating and measuring the schools' contribution to promoting student outcomes of various kinds (academic, affective, social and behavioural) and quantifying differences between schools (Harris, 2001). It is a relative, retrospective concept that is both outcome and time dependent and results depend on the adequacy of the statistical models used, e.g. the ability to control for differences in student intake (Sammons, 1996; 2007; 2010). In addition, it seeks to identify and study school and classroom processes that predict better outcomes for students while taking into account differences in student intakes (Mortimore et al, 1988; Scheerens \& Bosker, 1997; Sammons 2007; Teddlie \& Reynolds, 2000). There is an interest in studying schools' results across several years (three being the minimum to identify trends) in a range of outcomes. Taking these factors into account, an 'effective school' has been defined as:

$[\mathrm{O}]$ ne in which students progress further than might be expected from consideration of its intake. An effective school thus adds extra value to its students' outcomes, in comparison with other schools serving similar intakes. (Sammons, Hillman and Mortimore, 1995: 7)

In a similar sequence, the school improvement 'movement' grew out of a recognition that schools have the capacity to "make a difference" to pupil performance and achievement (Harris, 2002: 6 [original author's italics]), particularly if the conditions and culture of a school enable educational practitioners and young people to support and sustain the learning required in order to make such differences (Barth, 1990). The latter part of the last century saw the beginning of a shift - certainly in educational research literature and policy (Sammons, 2008) - from more 'prescription-driven' programmes of reform to a focus on devising strategies for improvement that match the specific contexts and development needs of students, practitioners and schools (Harris, 2002). The key focal points during the various phases of school improvement are generally understood to cover a combination of the following aspects, at different levels in Table 1.

[Table 1 here]

effectiveness' still applies and is relevant to the overall aims of the research and its sample, hence will be sustained for the remainder of this paper. 
Returning now to the potential role of resources offered via OUP Pathways in school improvement terms, the prospective contributions of internal and external influences during the various phases of school improvement (Harris, 2002) are explored. In the instance of the bigger study, Pathways and the resources provided by the OUP could potentially play a part in the manifestations of the 'external' roles suggested below in Table 2 .

[Table 2 here]

Next, considering other key elements that may influence educational change, Hopkins (1998) for example lists the following: "curriculum and instruction, organisational development and the decentralisation of decision making". Hopkins (1998) goes on to argue that the synergy and integration of these elements form a vital component of the improvement process. Certainly, in the case of the 2013 publication of the new National Curriculum, change was still making its way through primary schools across England where subject content has been altered, along with a reduction in the provision of materials, training and guidance to support teaching the revised curriculum. Documentation outlining the new National Curriculum highlights claims of increased teachers' freedoms and opportunities to build their school curriculum with less 'prescription' from central government (DfE, 2013a). Such claims may well be open to challenge. So change here may manifest in a combination of curriculum and instruction and a degree of decentralisation. In addition, schools would be looking to evaluate the outcomes of those changes in the form of student outcomes at a later date. This phenomenon points to how schools might go about evaluating the effectiveness of school improvement processes.

\section{Connections between school improvement and school effectiveness: potential and realised}

The forging of closer ties between the traditions of school improvement and school effectiveness is and has been a contentious issue, primarily as the two enterprises are in some ways philosophically premised on quite diverse aims and knowledge bases. School effectiveness is seen to travel from top to bottom or outside in, favouring researcher knowledge over practitioner experience while school improvement appears to constantly look for ways to change the system, working from inside out (Reynolds, Hopkins and Stoll, 1993), attempting to examine the events and relationships that represent a school's inner 'engineering'. However, there is increasing recognition that practitioners are more likely to understand the 'effectiveness' of a school if there is more knowledge surrounding the 'path' or sequence of events and their interplay that may have led to a change in student outcomes (Creemers, Stoll and Reezigt, 2007). This would include the voices of the practitioners and students treading that path so to speak; a charting of the school's educational practices and processes combined with the complex consequences of human interaction and networks that may have evolved and facilitated the outcomes over time. Crucially by the 
1980s, school improvement also evolved into something more than a 'travelogue' of journeys. Presenting itself was a rare opportunity for schools to take a step back and evaluate the processes and strategies for improvement that had just been mapped and catalogued (Reynolds, Hopkins and Stoll, 1993). The 1990s saw a new paradigm emerge called "Effective School Improvement" which was defined as:

[P]lanned educational change that enhances student learning outcomes as well as the school's capacity for managing change. (Creemers, Stoll and Reezigt, 2007: 2)

In this combined sphere, there are two primary criteria: one based on effectiveness and the other improvement. The effectiveness criterion asks: "Does the school achieve better student outcomes?" (Creemers, Stoll and Reezigt, 2007: 2). The improvement criterion poses: "Does the school manage change successfully?” (Hoeben, 1998) and build internal capacity for change. MacGilchrist, Myers and Reed's (2004) criterion meanwhile is how far the school is becoming an "intelligent school". They cite nine intelligences that guide schools towards addressing simultaneously and successfully their two main "core business" areas of learning and teaching while considering relevant applications of effectiveness and improvement research (MacGilchrist, Myers and Reed, 2004: xvi).

The dynamic model was chosen as a framework for this study as it focuses on influences on pupil attainment at different levels and also explicitly discusses the use of research evidence in schools for improvement purposes via the "Advisory and Research (A\&R) Team" (Creemers and Kyriakides, 2012: 64). The Advisory and Research Team in this instance matches well with the tentative roles played by this researcher, other academic support from the university and the OUP (via Pathways resources and its presentation of research evidence and guidance). This collaborative mode of working may also represent a more 'hybrid' approach that bridges the gap between SI (which purports to travel more 'inside out') and SE ('outside in').

Below are the essential characteristics of the dynamic model (Creemers and Kyriakides, 2012: 22-24)

1. Pupil attainment is influenced at four different levels: teacher, student, school and system. The multilevel nature of influences on pupil attainment has been emerging in effectiveness studies carried out in a range of national contexts (Teddlie and Reynolds, 2000).

2. School and system level factors have both direct and indirect effects on student achievement as they also play a role in teaching and learning contexts, and factors between levels may interact with each other.

3. How school and system level factors affect student achievement has to be structured and defined differently compared to the impact of classroom level factors.

Policy on teaching and actions taken to improve teaching practice must be measured over time and in relation to the weaknesses that occur in a school. The assumption is that schools and educational systems which are able to identify their weaknesses and develop a policy on aspects associated with teaching their School Learning Environment (SLE) are also able to improve the functioning of classroom level factors and their effectiveness status. Only changes in those 
factors for which schools face significant problems are expected to be associated with the improvement of school effectiveness. (Creemers and Kyriakides, 2012: 22)

Here it becomes clearer how the DASI model differs to other EER models; the impact of school and system level factors only takes into account very specific conditions and points of interest for improvement purposes in a particular context. This feature of associating improvement with a specific set of circumstances or chain of events links closely with the notion of Ofsted inspections serving as a "catalyst for change", particularly with regard to weaker or less effective schools (Matthews and Sammons, 2004: 12). Or indeed the use of school self-evaluation for developmental and formative purposes (Hopkins, 1989) in addition to accountability, external or otherwise, in order to guide decision-making and to achieve specific goals that make direct impact in the classroom (MacGilchrist, 2000).

4. The association of some effectiveness factors and achievement may not be linear; for example, the curvilinear relationship between teachers' subject knowledge and student achievement reported by Monk (1994) where knowledge beyond a certain point may hinder or have no effect on achievement in certain cases.

5. There is a need to carefully investigate the relationships between effectiveness factors, even within the same level, including the possibility of identifying particular groups of factors that yield better outcomes or those that impact more indirectly on attainment and possible interactions.

6. Another important difference of the dynamic model from previous models is crucial to the way this current study is designed; the DASI attempts to examine the qualitative characteristics of factors in order to identify more finely-tuned feedback on how each factor or combination of factors work and how they can be further improved. "[D]ifferent dimensions for measuring the functioning effectiveness factors should be used to collect data and provide constructive feedback to teachers and schools" (Creemers and Kyriakides, 2012: 25).

7. The Pathways study used as its methodology Design-Based Research, where essentially, "unravelling the multi-faceted interaction" between a particular intervention or activity and the context in which it is taking place is considered and even becomes the "explicit focus" of the research (McKenney and Reeves, 2012: 23). The activities in the wider study included:

a. schools' use of Pathways;

b. the design and redesign of the Pathways platform over time as the OUP receive formative feedback from its advisory group, school practitioners, this researcher and other relevant stakeholders and; c. schools' individual improvement practice and journeys. 
As for the empirical literature and making connections between evidence from SER and SI, Hopkins et al (2014: 273) summarise from earlier studies (e.g. Hopkins, Harris and Jackson, 1997) that schools at the lower-end of the performance continuum often require more in the way of "top-down intervention" compared to schools at the higher or middle range. One of the key findings identified by Sammons et al (2014: 580) in a study about the role of leadership in school improvement indicated that schools that began their improvement trajectory from a lower starting point:

made greater improvements in changing school culture, climate and addressing teaching and learning and use of performance data during the last three years.

Meanwhile, Harris et al (2013) draw attention to the "historic divide" between SER and school and system improvement research (SSIR) where practitioners might be aware of the factors associated with effective education but are still in the dark about the "processes necessary to put the effectiveness correlates in place" (Harris et al, 2013: 6-7). Hopkins et al (2014) reiterate the implications of research such as that of Day et al (2011) where 20 schools were found to have made sustained improvement and were able to increase autonomy (after establishing the "basic regularities" of schooling) that "there is a developmental sequence in school improvement narratives that requires certain building blocks be in place before further progress can be made" (Hopkins et al, 2014: 273). This study of five primary schools making efforts to improve is one such attempt at understanding those "building blocks". For example, how these blocks are defined and perceived by different stakeholders and the sequence of how each block is arranged and in what types of configuration in each school's different context.

The decision to use the DASI as a framework on which to build an evidence base in the study of school improvement processes in this study is also strengthened by the array of empirical research conducted over the last three decades and summarised by Creemers and Kyriakides (2015). For example, studies in the Cypriot context (Kyriakides and Creemers, 2009; Creemers and Kyriakides, 2010a), the European context (Panayiotou et al, 2013) and in Canada (Kyriakides, Archambault, \& Janosz, 2013). The Pathways study adds to this array as it explores the English state primary school context and tries to qualitatively understand the elements and processes associated with school improvement, specifically in the context of online technologies for practitioners.

The field of EER has made strong substantive and methodological links with the older field of teacher effectiveness, including the shared use of observation instruments (e.g. The ISTOF: International System for Teacher Observation and Feedback - Teddlie et al (2006)), qualitative investigation, and the development of newer understandings of teaching and learning (Muijs et al, 2014). Aside from the DASI which does take into account teacher effectiveness factors (Creemers and Kyriakides, 2006), one area that is peculiarly less established in EER is that of teacher professional development (TPD) (Muijs et al, 2014). According to Hattie (1999: 12): 
Like their students [teachers] must set challenging goals, seek feedback on the effectiveness of their teaching on students, and constantly be attenti[ve] to improvement and innovating the methods which optimise feedback and meeting challenging goals.

Notwithstanding the numerous issues around clarity and agreement over the measurement of teacher effectiveness (Muijs et al, 2014), understanding teacher behaviours, teacher professional development and their relationship with changes in pupil outcomes is a critical element of developing improved education systems (Muijs, 2006; Borko, 2004; Marzano, 2003; Brophy and Good, 1986). Guskey (2002) identifies five levels on which CPD should be evaluated in schools. Discussing how schools might move beyond Level 1 (shown in Table 3 below) Guskey and Yoon (2009: 498) assert that practitioners at all levels should demand higher quality evidence from educational consultants, programme designers and resource providers: "[s]tories about what happened at one time in a single school or district may be interesting, but they do not justify broader implementation".

[Table 3 here]

The aim of Guskey's framework is not to collect 'proof' of impact but good quality evidence that indicates whether an online programme or professional development may have contributed to specific gains in pupil learning (Guskey, 2002). To plan a successful programme, designers should start from level 5 and work backwards - critical analyses of pupil assessment data, examples of pupils' work and other data such as attainment targets might be useful starting points to identify pupil learning goals. This is usually followed by investigating what instructional practices and structures might most effectively facilitate those outcomes, from both teaching and learning perspectives (Guskey, 2002). Furthermore, Muijs and Lindsay (2008: 199) in their empirical investigation of Guskey's five levels as a framework to evaluate CPD identified an additional level - cost-effectiveness of different modes of CPD.

\section{Methodology}

This study uses a multimethod embedded case study approach. Debates on the definition of 'multimethod research' endure in the literature, along with its demarcation from 'mixed methods research'. Hesse-Biber and Johnson (2015), editors of the comprehensive Oxford Handbook of Multimethod and Mixed Methods Research Inquiry, refer to the whole subject of the handbook as MMMR; mixed methods research is shortened to MMR, while multimethod research has no abbreviation. In this article, we will refer to multimethod research as MuMR.

In particular, a qualitatively driven MuMR approach was employed in designing interview schedules with practitioners and analysing a range of other data sources including school attainment and progress data, 
school improvement and action plans and artefacts resulting from Pathways and staff meeting discussions. A high degree of flexibility was exercised during each field visit in how data was secured from practitioners and the varied settings that I was allowed to access - for example, more formalised all-staff meetings, interviews that transformed into more informal discussions as early career teachers and the headteacher came together to evaluate the research project and smaller planning meetings in different spaces.

Some argue that qualitatively driven multimethod research differs from pluralism in qualitative research, in which qualitative methods are combined as they are in multimethod designs but there is more flexibility about the status of the methods used ... Depending on the reason for their introduction to the study and the stage in the research process at which the decision is made to use additional qualitative methods, each qualitative method may be afforded equal, adjunct, or greater status in its use to address a research question or evolving set of research questions. (Hesse-Biber and Johnson, 2015: 6)

The full study also attempted to introduce opportunities for fulfilling the five purposes for mixed methods designs advanced by Greene, Caracelli and Graham (1989: 259) - which we would argue are equally applicable to MuMR designs:

1. Triangulation - seeking multiple sources of evidence by systematically using different methods over time in an effort to reduce researcher bias and open up new possibilities both substantively and methodologically for the study and its participants;

2. Complementarity - enhancing the ability to build a richer picture of a site's context and school improvement journey by studying different perspectives and exploring newer, perhaps uncharted aspects;

3. Development - using one method to develop or inform the next, allowing for a degree of flexibility in steering the direction and scope of the research. For example, in the Pathways research - as illustrated by the Magpie School case study, working between the "co-learning agreement" between researcher and participants afforded by the DBR approach (highlighted next) and the collection and analysis of multiple sources of data to enrich that approach;

4. Initiation - being open to contradictory or paradoxical results and not being afraid to ask difficult questions that do not align with previous assumptions or beliefs;

5. Expansion - selecting the most appropriate mode of inquiry for each task. For example, while it was not possible for this researcher to sit beside each practitioner and observe their use of Pathways in real time, as highlighted in the Magpie School case study here, I opted to instead observe (and participate) in discussions between the headteacher and the teachers managing Pathways to try and understand how roles and plans were negotiated, and indeed if and how Pathways materials featured in those discussions. 


\section{Research strategy: Design-based research (DBR)}

The Pathways study addresses the research objectives and questions listed earlier using DBR. The DBR approach is generally viewed as a research methodology rather than a design methodology (Reimann, 2013: 44). Reimann (2013: 45) also traces its "intellectual pedigree" back to experimental educational psychology, design research in the natural sciences and engineering and participatory methods employed when designing new software.

Design experiments were developed as a way to carry out formative research to test and refine educational designs based on theoretical principles derived from prior research. This approach of progressive refinement in design involves putting a first version of a design into the world to see how it works. Then, the design is constantly revised based on experience, until all the bugs are worked out. (Collins, Joseph and Bielaczyc, 2004: 18)

Collins, Joseph and Bielaczyc (2004: 16) put forward four essential factors that support the use of DBR in the context of studying approaches to learning and development; the need:

- to address theoretical questions about the nature of learning in context [current author's own emphasis];

- for approaches to the study of learning phenomena in the real world rather than the laboratory;

- to go beyond narrow measures of learning; and

- to derive research findings from formative evaluation.

This approach does not assume that any simple concepts of 'what works' can be identified, though it is intended to provide helpful input into theories of school improvement and to inform practice and practitioners. Nor does it assume transferability in different contexts though again, "fuzzy generalisations" (Bassey, 1999) may be possible. The aim is to - like Flyvbjerg (2004: 400) in his treatise on "five misunderstandings about case study research" - "demur from the role of omniscient narrator and summariser" but tell each school's and Pathways' story in its rich complexity, from different perspectives which may coalesce and conflict. I was attracted to the design-based research approach in conducting this exploratory study due to its explicit focus on studying change and evolution of resources and for the large part, technological tools to support improvement in some way in practical contexts. This aligns well with the focus on the development, use and evolution of Pathways, the underlying aim of studying schools' improvement journeys and processes, as well as the wider social setting.

[T] he main goal [of social research] is improving understanding of how things work in their particular settings. That information may be useful for improving the thing studied, but aiming the research directly at improvement [in decision making] risks failing to examine adequately the complexity of the way it works. (Stake, 2010: 122)

Parallels can be drawn between the principles that underpin DBR and those of SI. McKenney and Reeves (2012: 1) suggest that the basic idea of carrying out DBR, particularly for the first time, can be seen as "educational intervention" in itself: 
We know from our own research and experience that sustainable use of new ideas does not come when an intervention focuses on using new resources or changing overt behaviours. Real change can come when we focus not only on what and how things can be done, but when we also work to understand why. (McKenney and Reeves, 2012: 1)

In the quest for deeper understanding of school effectiveness and how schools go about their planning, practice and evaluation, the field of school improvement has grown and can be further extended using techniques such as DBR, in order to study complex processes happening in situ, as this study aims to explore and illustrate. The following overarching DBR-focused principles were applied to the wider study's methods:

- the "co-learning agreement"3 which denotes a particular style of interaction between researcher and practitioner that incorporates notions of "reflexive, systematic inquiry", participation in ongoing action and reflection and initiating change within individual institutions (Wagner, 1997 in McKenney and Reeves, 2012: 18). The researcher acts as a "researcher-practitioner" while the practitioner fulfils the role as "practitioner-researcher" in each of their 'home institutions' (Wagner, 1997: 17). This mode of inquiry is aimed at making stronger links between the research methods, collected data and the data analysis and interpretation that will follow in the research design. Knowledge is collected, shared and interpreted on a cooperative basis between researcher and practitioner (for example via the means of Pathways self-evaluation tools) and changes proposed and/or put in place at the OUP and individual schools;

- data was collected across a range of perspectives - i.e. the OUP, this researcher and university academic support that acted as expert advisers on Pathways - and school practitioners at different levels of management. Different sub-frameworks were applied to each perspective, with the predominant approach drawn from Organisational Learning (Argyris and Schön, 1978) and Knowledge Management Feedback systems literature (Bain and Swan, 2011);

- components of design-based research or educational design research ${ }^{4}$ projects (McKenney and Reeves, 2012: 27) were identified and applied - (a) the main foci (research objectives and research questions) of the study; (b) the development of the intervention, i.e. Pathways and schools' responses to Pathways and other tools for school improvement; (c) the theoretical contribution and relationships with Pathways; (d) research methods and research scope that support the investigation of (b) and (c); (e) methods and interpretations that are predicated on data collected

\footnotetext{
${ }^{3}$ This is in contrast to two other styles of cooperation identified by Wagner (1997: 17) - "data extraction agreement" and "clinical partnership". The former entails the "researcher as researcher and practitioner as practitioner" while the latter the "researcher as researcher \& collaborator and practitioner as practitioner and collaborator".

${ }^{4}$ McKenney and Reeves (2011: 18-19) express a preference to use the term "educational design research" to distinguish from design research situated purely in engineering and human computer interface design environments. This paper uses "design-based research" to cover a wider reference base beyond the McKenney and Reeves volume.
} 
using "reciprocity between research and practice" McKenney and Reeves (2012: 17) $)^{5}$ and (f) practical and substantive contributions to knowledge.

Another key aspect of the research design offered opportunities to produce artefacts based on each school's data and then re-present those artefacts back to school teams, which was taken up by Magpie School (Figure 6), featured in the next section. After following the school's improvement journey for two years, an infographic-style illustration of their trajectory was produced based on their Ofsted reports and presented back to the headteacher and then discussed as a further source of data on which to base the next stage of their improvement planning. The ensuing conversation could then be fed back into the data collection cycle and re-analysed in its new, altered form by undergoing another round of debate and rationalisation.

\section{Methods}

Depending on the research question, different methods were employed, with a focus on specific perspectives (schools, OUP and this researcher). There were sometimes stark differences in approaches, e.g. eliciting views and perceptions from practitioners on the functionality of the platform (RQ1) required mainly data derived from interviews and observations in schools. In contrast, developing an understanding of how the evolution of Pathways was shaped and reconfigured based on inputs from the OUP, schools and this researcher (RQ2) called for interviews, meeting observations and gathering documents with platform designers, steering group members and other stakeholders at OUP and school practitioners at different levels, along with a clear articulation of my involvement in the project, as the researcher, intermediary between schools and the OUP, and design-based research 'agent' for the study. Hence, one of the sets of theoretical assumptions underpinning this research is the idea of "dynamic systems", which have four central features in common (Earl and Katz, 2006: 102):

- a process that operates on an iterative basis, and evolves over time;

- a process that has a feedback loop;

- a context that includes internal constraints that shape the image or micro-level subsystem in question; and

- a context that sets external constraints that shape the actual organisation or macro-level structure that takes place (Katz, Sutherland and Earl, 2002).

\footnotetext{
${ }^{5}$ Notions of "reciprocity between research and practice" as advocated by McKenney and Reeves (2012: 17) where the "social design of research projects" (Wagner, 1997: 19), in particular the cooperation between researchers and practitioners becomes an essential component of the study's design.
} 
While these types of systems are unlikely to function neatly in the above order, an important principle of the research project as a whole was to capture an understanding of each of the features and how they might assemble as a system of sorts in the particular contexts of the study.

\section{The illustrative case study}

Magpie School, located in south east England, gets its pseudonym from its headteacher (on several occasions during the research project) equating 'sharing good practice' amongst schools at training events and courses with 'magpieing' ideas from each other. The term 'magpieing' is not unique - particularly in the literature around children's reading strategies and developing ideas for writing - and increasingly can be seen in documentation and articles related to school improvement (Rowland, 2015; Doherty, 2015). Writing for the National College for School Leadership, Aitkin and Spellman (2002: 2) called for a "magpie approach to improving teaching", where new ideas are sought but not adopted indiscriminately, with teachers "selecting what works in the school context and blending a range of approaches for success".

\section{School context}

Magpie School is a mixed, urban primary school in the south east of England. Pupils at Magpie are aged 3 to 11 years (which includes nursery, foundation stage and year groups 1 to 6). At the start of the 2015/16 academic year, there were 479 pupils on roll, making this a larger than average primary school. The average number of pupils per state-funded primary school in England as of January 2016 is 275 (DfE, 2016a). Magpie began as a 'first school' and later became a primary school in 2004. In November 2009, a consultation began for the school to increase its Year 1 intake from 45 to 60 pupils, making Magpie a two-form entry school. 28 percent of pupils have been classified by the school with Special Educational Needs (SEN) status. This is well above the national average. Nationally, in 2016, 13.4 percent of pupils are reported 'with SEN' (either 'with statements or [Education, Health and Care] EHC plans' or 'with SEN but without statements or EHC plans'). The Warnock report (House of Commons, 2006: 28) stated that in 2005, 18 percent of all pupils in England had "some sort of SEN" and that this number was decreasing gradually from a peak in 2001. In 2007, the DfE reported 19.3 percent of all pupils in England as 'with SEN'. A local authority Autism Resource Base (ARB) adjacent to Magpie School caters for 13 pupils, all of whom have a statement of SEN. 34 percent of Magpie pupils have English as an additional language (EAL). While most pupils are identified as White-British in the school, the remainder are from a wide variety of ethnic backgrounds - the highest being White-Other and Pakistani. The percentage distribution between boys and girls is 57 percent and 43 percent respectively - a higher than average percentage of boys. (Nationally there are 51 percent boys and 49 percent girls.) The proportion of pupils 
eligible for free school meals at any time during the past 6 years is 17.9 percent, which is below the national average of 25.4 percent.

The headteacher (referred to Mrs Magpie from this point forward) stated that Magpie "used to be a school with lots of problems" but they had "turned it around", and now staff were more likely to stay put:

'People don't want to work in schools that require improvement because it's more work." [Mrs

Magpie_MS_Dec-20146]

She added, however, that too few people are joining the teaching profession, and some cities attract fewer applications for teaching posts because of the high cost of living:

"If a job is advertised - five years ago, there would be 70 people applying, now you'll be lucky to bave five applying.”[Mrs Magpie_MS_Dec-2014]

Mrs Magpie herself had been in post at Magpie for nine years. She joined the school as a Key Stage ${ }^{7}$ (KS)1 Coordinator in 2002, then moved up to Deputy Headteacher before being appointed headteacher in 2006.

\section{Attainment and progress}

The fieldwork for the whole research project took place between 2014 and 2016, which coincided with a change to the National Curriculum in England and hence, changes to key stage (KS) 2 and KS1 assessment and the publication of schools' results in England. In order to provide some pupil performance context to the school case featured in this article, Figures 3, 4 and 5 show five years' worth of KS2 attainment and progress results between years 2012 and 2015 in:

- mathematics;

- English (reading and spelling punctuation \& grammar tests and writing teacher assessments) and;

- progress measures from KS1 to KS2 in reading, writing and mathematics.

2014, 2015 and 2016 would have been crucial years during which to examine pupil performance in national tests for the schools taking part in the research project, along with their patterns of use of Pathways. However, this period also saw the transition and eventual change to the new National

\footnotetext{
${ }^{6}$ Denotes that this quotation belongs to the headteacher (Mrs Magpie) of Magpie School (MS) during an interview that took place in December 2014.

${ }^{7}$ The National Curriculum in England is divided into blocks of years or 'key stages' (KS). Pupil assessments take place at the end of each KS. At primary school level, KS1 consists of Years 1 and 2, and KS2 is made up of the remaining primary Years 3 to 6 . At the end of Year 6 or KS2, pupils sit for national tests and teacher assessments in English and mathematics, and teacher assessments in science. [Source: https://www.gov.uk/nationalcurriculum]
} 
Curriculum and assessment procedures (DfE, 2013a). So, while it would not have been possible or advisable to make any causal claims, it would have been useful to try and understand some of the school improvement processes along with any tentative links between the use of resources like Pathways and results trajectories during this crucial changeover period. While comparisons cannot be made between results published in 2016 and the ' 2012 - 2015' period, what can be done is a study of schools' trajectories between 2012 and $2015^{8}$. Any connections and claims made in relation to Pathways during this period will also of course be tentative. It would also be possible to analyse and draw tentative conclusions from how different schools described their policies and practices in planning for and implementing the new National Curriculum, how practitioners dealt with the uncertainties of the new assessment system without levels, and the communications they had with parents and carers about managing their expectations.

Next, Magpie School's attainment and progress data will be discussed.

[Figure 3 here]

Figure 3 focuses on Magpie's impressive reduction in the attainment gap between pupils with English as an Additional Language (EAL) and non-EAL pupils - as 34 percent of Magpie pupils are identified as EAL. Figure 4 shows a generally increasing trend in KS2 reading, mathematics, and bar a dip in 2014, in writing. My first visit to the school was in December 2014, one day before the national publication of the primary school performance tables. Mrs Magpie talked about ways to "break the chain", to make connections between strategies that might lead ultimately to improved pupil outcomes, and putting together a plan to engage more parents:

'I $t$ 's going to be a good year. Our writing's down, but it's [down] all over the country. Our argument is that if children can't speak, they can't tell a story, they can't write a story. They can't read, they can't write a story. The only way they're going to talk is via the parents. We have something called the Big Talk on a Thursday evening. Most parents don't do it. Teachers give them the plans for what they're going to write on the Friday to take home and talk it through with their parents. If the children haven't got any ideas, you know the parents haven't talked to them. Even if it's while driving to school, those five minutes, sitting over a meal. Showing children get parental support.”[Mrs Magpie_MS_Dec-2014]

\footnotetext{
8 Indeed, even comparisons between 2015 and pre-2015 cohorts were made more difficult due to the complete redesign of the DfE performance tables website during the change of government from 'Conservative-Liberal Democrat Coalition' to Conservative in 2015. Year-on-year comparisons between 2012 and 2015 cannot be viewed or easily made without first 'hunting' for and extracting the 2015 data set in a suitable format on the new 'https://www.compare-school-performance.service.gov.uk/' site.

${ }^{9}$ The school experienced another dip in Writing TA in the 2016 KS2 assessments. The assessments are based on the new National Curriculum and so are not comparable with previous years' results, but Writing could be one of Magpie's school improvement foci for the next year.
} 
At a later interview, she continued to explain the challenges of getting more parents involved in their children's learning, and listed the different strategies being considered and trialled - I have identified each with a number in square brackets:

'We had three reading workshops last year, the parents that didn't need to come came. [1] We need to get out and find out why the others are not coming. 'Oh, we've got little ones'. [2] The crèche needs to be advertised more. Our Pupil Premium ${ }^{10}$ children tend to have little brothers and sisters. Because of that the parents don't come. But they're the parents that tend not to be at work so they should come. Other parents take time off work to come to the workshop. [3] We bave to find a way of getting the parents in. Break the chain. [4] Making the timing convenient is important. 9 am - drop off time, [is] good. [5] Cookery class with parents on Wed morning, parents who wouldn't normally come into school. But because they drop the children off, I grab them and say come and 'do some cooking?. [6] Need to have something on offer, cooking, bag of freebies, or get children involved in workshop. [7] We've got a double-decker bus now. Got all the children out onto the playground, they thought they were going to be told off. [Showing video of bus arriving] Carpeted bus. Secondary kids broke into it but now we can lock it securely.”[Mrs Magpie_MS_Aug-2015]

Mrs Magpie also revealed a complete change in strategy to deal with the previous year's KS2 results trying to understand where Magpie's priorities lie, again making connections - and praising Pathways for coming along during the implementation of the new National Curriculum:

"For the last three years, we were flogging a dead horse focussing on writing. But without reading, there was no point. If Ofsted comes and sees your writing is low, you have to have it on your action plan. Big Write, Big Talk, P4C [Philosophy for Cbildren], [we are] going for [the] bronze [award]. We've introduced values instead of rules. [I am] so pleased to see Pathways - it provides a structure. I was looking for a strategy in 2013, found Pathways, has changed it for us.” [Mrs Magpie_MS_Aug-2015]

[Figure 4 here]

[Figure 5 here]

On the subject of accountability and performance, Mrs Magpie articulates a personal view that the reliability of Ofsted judgements is not always high and that there is "no such thing as an Outstanding School":

"I believe very strongly [that] good schools can have something they are outstanding at. We want to be outstanding in reading but we are not an outstanding school. I believe schools are good, solid schools. If we become a school that is outstanding in reading, we can share that expertise with other schools. [It's] not looking at the real world. I went

\footnotetext{
${ }^{10}$ Pupil Premium is additional funding provided by the English Government to publicly-funded schools. The funding is meant to help disadvantaged pupils achieve better educational outcomes and close the gap between them and their peers. [Source: https://www.gov.uk/guidance/pupil-premium-information-for-schools-andalternative-provision-settings]
} 
to visit a school in London [that was judged to be] outstanding, but it seemed good with outstanding features. They might have been outstanding for those two days.” [Mrs Magpie_MS_Dec-2014]

It is worth noting that Magpie was judged 'Good' in 2013. Their Ofsted history (taken from a recent research poster created by the authors depicting Magpie School's general performance trajectory) is illustrated below in Figure 6 .

[Figure 6 here]

At this point in the interview I privately question how a school can realistically be outstanding for only two days, and how that would manifest from the school's point of view and Ofsted's. On closer 'inspection', Mrs Magpie's comment fits with the broader context of changes in the Ofsted framework that have taken place over the last ten years intended to raise the bar - many 'Outstanding' schools found (and continue to find) that they have been downgraded. Some more specific questions related to Magpie School are addressed next, from a DBR perspective.

\section{School improvement priorities}

Before this research project began, schools that expressed an interest in participating in the research project were asked to complete a questionnaire detailing:

- the background and context of their school;

- school improvement plans and practice (including tools and resources used and partnerships with other schools) and;

- why they would like to participate in the research project.

The problem for Magpie School - in the context of their school improvement plans and this research project - can be illustrated in part using the reasons given by the headteacher for why they volunteered to participate in the project:

"It is becoming more difficult to train teachers without the correct resources. We used Oxford Pathways for the New National Curriculum and it helped remarkably. I shared this with the 13 schools in the partnership and many of them used it. I am hoping that we can get more involved with the new Pathways. The new Outstanding reading schools Pathways will [help] our whole school focus tremendously.” [Mrs Magpie_MS_Oct-2014]

Mrs Magpie stated once the research project began that the school needed to involve parents more in the learning process. Other school foci were given as: "improving reading for pleasure and becoming an outstanding reading school \& improving phonics and writing in early years." The headteacher also talked 
about the need to improve the transition between early years and KS1 - particularly around the gap between the Early Learning Goals ${ }^{11}$ in the former, and working out where the children are meant to 'be' within the National Curriculum framework: "It's a wasted transition time." She expressed a hope that transition might be improved with the removal of National Curriculum levels. However, she also expressed her view that levels are not really 'going' anywhere but are merely being renamed, because schools were now expected to define attainment and develop ways to measure progress themselves.

\section{Engagement with Pathways}

Each case study in the fuller research project details practitioners' engagement with Pathways using Guskey's "Critical Levels of Professional Development Evaluation":

(1) Participants' reactions - initial and ongoing reactions to the content and structure of Pathways (and other resources if applicable);

(2) Participants' learning - did users acquire the knowledge and skills they thought they would?;

(3) Organisational support and change - was the implementation of Pathways facilitated in the school? If so, how was support exhibited? and where possible;

(4) Participants' use of new knowledge and skills - did users report being able to effectively apply their new knowledge and skills, and what evidence was there of these applications?

Guskey lists a fifth level: (5) Students' learning outcomes, however due to this study's design and objectives, it was not possible to causally link pupils' learning outcomes in the case study schools directly to teachers' use of Pathways. Tentative links were made between practitioners' articulated and observed experiences with Pathways and specific improvement tasks and plans outlined at the start of the research project. According to Guskey (2002: 46):

With each succeeding level, the process of gathering evaluation information gets a bit more complex. And because each level builds on those that come before, success at one level is usually necessary for success at higher levels.

\section{Level 1: participants' reactions towards, and engagement with, Pathways}

The main stakeholders in this part of the DBR project are depicted in Figure 7, indicating Magpie's prior 'consumer' relationship with the OUP and the newer relationship in the study:

[Figure 7 here]

\footnotetext{
${ }^{11}$ Early Learning Goals are the knowledge, skills and understanding pupils should have at the end of the Early Years Key Stage (at the end of which pupils turn five years old) [Source: https://assets.publishing.service.gov.uk/government/uploads/system/uploads/attachment_data/file/596629/EY FS_STATUTORY_FRAMEWORK_2017.pdf]
} 
The extent of Magpie's engagement with Pathways is highlighted next in Figure 8.

[Figure 8 here]

Magpie proved to be a rich source of material in my exploration of how primary schools took to Pathways and what could be learnt about their approaches and strategies to support school improvement and promote teachers' learning and professional practice. The headteacher spoke quite openly about her pupils' attainment and progress, and challenges faced among the staff in their efforts to improve outcomes for all children. She volunteered to participate in this research project having been a consumer of OUP resources previously, had just 'finished' one Pathway (Managing and Implementing the New National Curriculum), and was in the midst of completing another two (Building an Outstanding Reading School and Parental Engagement).

This school's use is exemplified by the headteacher's application of the Teaching and Learning Responsibility 3 (TLR3) scheme to remunerate early career teachers to manage individual Pathways as part of an integrated school improvement plan and to foster professional development. With two years' teaching experience, Ms ECT2 ${ }^{12}$ was awarded the TLR3 to manage and implement the new National Curriculum Pathway. Two other teachers (referred to from this point forward as Ms KS1 and Ms KS213) began jointly managing the Parental Engagement Pathway in 2015, also on the TLR3.

TLR3 payments are made to qualified teachers (at any level of experience) to carry out short- or fixedterm projects in their schools. The National Union of Teachers (NUT, 2013: 1-2) states that: "In order to qualify for a TLR payment of any kind, teachers' duties must include a significant responsibility that is not required of all classroom teachers and that

a. is focused on teaching and learning;

b. requires the exercise of a teacher's professional skills and judgement;

c. requires the teacher to lead, manage and develop a subject or curriculum area; or to lead and manage pupil development across the curriculum;

d. has an impact on the educational progress of pupils other than the teacher's assigned classes or groups of pupils; and

e. involves leading, developing and enhancing the teaching practice of other staff.”

TLR payments came into force in September 2013, as a fixed-term teaching and learning allowance (DfE, 2013b).

\footnotetext{
${ }^{12}$ Ms ECT2 refers to a teacher at Magpie who has been anonymised. The code is as follows: ECT=Early Career Teacher and 2=Two years' teaching experience.

${ }^{13}$ Ms KS1 denotes a female teacher with one to two years' experience, teaching in key stage 1. Ms KS2 denotes the same but in key stage 2 .
} 
Pathways was articulated by Mrs Magpie as more of a "strategic element" compared to operational-level responsibilities. The headteacher recommended "starting at the top" and touched on the topic of continuity planning and the 'precarious' nature of maintaining knowledge within the school:

'Unless you've got the backing of the headteacher for Pathways, it's not going to work. Take it from me, you can go into a school in [another city], speak to a class teacher, unless the senior leadership are supportive, it will stay in that one classroom. If it doesn't come from the top, it won't work. Keep it whole school. People can leave at any minute.”[Mrs Magpie_MS_Dec-2014]

One way to read this comment is to question Magpie's strategies for embedding organisational learning the fear of teachers leaving with knowledge and the remaining school workforce having to re-learn or worse, work backwards to 'undo' previous mistakes and fix problems without relevant information. The other way to look at this is Mrs Magpie's assertion that teachers' autonomy and professional development are important, but ultimately, they need to be underpinned by leadership support. Mrs Magpie sees the school as far more strategic than in the past, along with schools in England in general: schools, she says are more 'data-led', and 'results-driven"'. A theme of 'follow-through' from plans to action accompanied the headteacher's descriptions of how her school worked. The school had 'Must sheets' - documents that list the more "business as usual" aspects of school operations. For example, there were Must sheets for the teaching of mathematics and for behaviour - including a code of conduct for the use of Facebook and other social media. The Must sheet acted as a checklist for teachers to verify the tasks that 'must' be carried out (or non-negotiables) in the school as part of a specific strategy, and was periodically revisited so teachers are reminded of things that needed to happen; and explain why, if they had not.

Another example of 'follow-through' was detected from the headteacher's reference to staff meeting minutes as "our minutes, not my minutes", meaning that the minutes belonged to her and her staff team She did acknowledge however, that actions from meetings did not always happen, and a discussion to address this had taken place the previous week:

"E]very meeting now, we go back and say what happened last week, what did we say we were going to do, and it's about people doing what they said they were going to do. Nine times out of ten in schools, someone has a great idea and within three months the school has moved on and forgotten it. We're trying desperately to go back to what we said we were going to do and doing it. And that's the 'Must' sheet again.” [Mrs Magpie_MS_Dec-2014]

A constant theme running through the interactions I observed between Mrs Magpie and different classroom teachers can be encapsulated as one of mediated autonomy. This is not meant in the Hegelian sense where autonomy is articulated as an ontological or ethical phenomenon (Williams, 2001: 1) but as something more functional, akin to 'distributed leadership'. The idea of the latter places an emphasis on 
the leadership being diffused among different members of staff, whereas referring to events at Magpie School as being characterised by 'mediated autonomy' shifts the emphasis of the perceived freedom to act onto the staff, but also 'refereed' by the headteacher (and others in the senior leadership team) at different points. The headteacher explained the rationale behind the TLR3 and how it is "perfect" for what is required of the particular Pathway started a year before - Managing and Implementing the New National Curriculum $^{14}$ :

"You have to bave it [Pathways] strategic from the top. The person chosen was not a senior leader but was felt to be ready to take on a project. She came to the SLT [Senior Leadership Team] meetings and staff meetings to deliver. It raised her self-esteem, her career; built her confidence. She's in her third year of teaching - she will go on to do something great.”[Mrs Magpie_MS_Dec-2014]

So here, it is argued that 'autonomy' would describe the classroom teacher's ability to shape an action and/or outcome (Norman, 1994: 27), in this case, to influence how she and her colleagues might choose to manage and implement the new National Curriculum. The 'mediation' would be derived from the headteacher's own autonomy and ultimate decision to appoint a member of her team to manage a particular Pathway (or 'learning walk') and provide 'buy-in' at the leadership level. This buy-in would include the language and structures required to support the team's subsequent course of action in managing a particular issue and Pathway.

\section{Level 2: participants' learning from CPD and observed drivers for change}

Several drivers for Magpie's engagement with Pathways were observed. First, Mrs Magpie appeared to be an "ardent supporter" of OUP resources and range of services, and acted as an advocate to other schools, occasionally even in international contexts. Second, Mrs Magpie articulated that the advice on improving parental engagement would be "coming from an external \& professional body (OUP)" and not just the headteacher (or "muggins", as she later referred to herself).

'It's not just coming from me. It's a whole professional body like OUP. They prefer it to be a professional body. Here's a questionnaire, here's an audit, much easier for me. Launch at the staff meeting, [we will] use [the] Parental Engagement booklet to work alongside. That'll be my tool for the INSET day. Bring it with you. A lot of downloading [otherwise] if online. Asking teachers to download one page from somewhere online [is difficult]. Each page is an action point. We can work through each point - the same points in the book as in the exemplar in Pathways. “[Mrs Magpie_MS_Aug-2015]

Linked with this idea of 'sharing the load', Mrs Magpie articulated a similar view on teachers' professional development.

\footnotetext{
${ }^{14}$ The introduction of the new National Curriculum was an immense policy change in England, hence why the NC Pathway was offered to schools for free on the launch of Pathways in 2013.
} 


\section{Teachers' professional development context in Magpie}

A mixture of inter- and within-county training was seen - by the headteacher - as the go-to option for professional development, rather than training delivered solely in or targeted towards the one school. Mrs Magpie listed the local authorities where recent training has taken place and been successful. She remarked that twenty years ago, training would be more likely to happen within one's local authority (LA) and the cost of different courses could be very high. The theme of sharing carried through to professional development within the school, with the use of peer observation:

'What happens is, I give them a teacher standard, [which] relates completely to our SIP. E.g. 'set goals, stretch and challenge pupils of all backgrounds'... [which is] 1.2 of the teacher standards. Teachers are then paired up and they bring [observations] back to me. We do [teaching assistant] TA peer observations as well. It would be in... this folder... of good practice observed, what needs to be developed... I would have to go through those in term 5." [Mrs Magpie_MS_Feb-2016]

In combination with peer observation, a further example of follow-through was seen in the school's approach to monitoring pupils' writing progress:

'You'd have the Deputy Head, doing a 'learning walk' to see how things are happening. We have peer observation, people monitoring a specific subject, and we have writing moderation three times a year in our staff meeting.”[Mrs Magpie_MS_Feb-2016]

The headteacher showed a keenness towards more collaborative professional development, where training courses were shared amongst groups of schools - other schools were invited to attend courses, Magpie School may have acted as a venue, and teachers would have the opportunity to learn what other schools were doing and how. When asked about the advantages and disadvantages of having training with other schools present - for example, with just one school, training might be more tailored to that school's particular context and set of experiences, with multiple schools, tailoring can be more difficult - the headteacher answered:

'I would say the wider the field, you are going to get good questioning, because you've got a bigger field. People in one school know each other, and it's a bit like, if you make mistakes, you learn more. Therefore, if you're in a room with people sharing good practice, saying 'we don't do that', it's not good to think therefore we're not going to do it. You see how people do something in another school and you can see, ah, that's where I've gone wrong, this is a much better idea... By hearing what other people do in their school, you learn, get much better advice. It's called magpieing15, we magpie everything with teaching. Sharing good practice.”[Mrs Magpie_MS_Feb-2016]

Mrs Magpie's prime concern was interpreted as a need to promote good practice in teaching and learning using professional development and appropriate resources from a range of providers, including the OUP,

\footnotetext{
${ }^{15}$ An example of how an idea was magpied from another school can be found in the 'DBR moment' example before the Concluding Remarks section.
} 
other schools and so on. She elaborated on what she saw as collaborative professional development, the idea of working with other schools, learning from each other's mistakes as well as good practice:

'Working together, with other schools, with secondary schools, with other staff. If you take the training to staff meeting and share it with others, it makes it collaborative. You go and observe someone else doing something different.”[Mrs Magpie_MS_Feb-2016]

This extended into "general relationships and collaborative working" practices at Magpie that Mrs Magpie seemed to espouse when asked how she goes about convincing staff and students of an idea: "not telling them, but giving them options." 'Two early career teachers at Magpie (mentioned earlier and referred to from this point forward as Ms KS1 and Ms KS2 ${ }^{16}$ ) discussed the issue of building connections with some openness:

"There are a lot of quick staffroom chats where you have to have a good rapport with someone to be able to say 'We're doing this... What do you think? Would you be interested?' and without them even knowing we've already agreed it. That's happened quite a lot.” [Ms KS2_MS_Feb-2016]

The school was looking to implement a new structure for homework in order to improve parental engagement. The teachers both discussed the idea of making staff and students feel like "they have options" in the decision:

'It'll get taken to student council and it will feel like it was their idea, but [the named teacher council chair] will make them choose that one. But they would have chosen that anyway, it's more colourful.” [Ms KS1_MS_Feb2016]

Autonomy, or the perception of it, was also mentioned when asked about how the early career teachers managed their Parental Engagement Pathway as newer members of staff at the school:

'Not standing on other people's toes. If it's someone else's area, to run it by them to make them feel like they've been included before we give it to the rest of the staff, making sure they have autonomy. We have an idea: Young Interpreters Club' with hats and badges. They're going to show people, new families around the school - child-led. We had to make sure to talk to the EAL person. [Mrs Magpie] suggested speaking to them. We wouldn't have thought of speaking to them. Because we're so driven by parental engagement.”[Ms KS1_MS_Feb-2016]

The feeling of autonomy amongst staff was brought up again when I asked the teachers how it was decided which year or class they taught:

"In this school, we get asked which year you prefer, quite unusual. [Mrs Magpie] will always try to accommodate. We're always allowed to go on courses. I just went on a course for $£ 400$ in London P4C Pbilosophy for

\footnotetext{
${ }^{16}$ Ms KS1 denotes a female teacher with one to two years' experience, teaching in KS1. Ms KS2 denotes the same but in KS2.
} 
Children]. We're going for the Silver award. I've gone on level 2 training. When I've completed my homework, we can go for Silver, I think. we're there already.” [Ms KS1_MS_Feb-2016]

This was balanced with the idea of mutual expectations and a culture of improvement:

'In this school, the ethos is not to just sit back and cruise. You have to show that you're improving and give back.”[Ms KS2_MS_Feb-2016]

\section{Level 3: Organisational support and change}

Some thoughts on how a problem is identified and described - and the role of reflexivity on the part of the researcher In the case of Magpie School, I was both an external observer and somewhat 'internal' in that I had been visiting this school regularly and had learnt a variety of things about them, particularly at staff meetings. Trying to get to grips with the challenges being articulated by different practitioners at Magpie was becoming a challenge for me too. But after developing a relationship with this school for over a year, I also felt I had to pick my moments carefully when to ask difficult questions.

I had just met with Ms KS1 and Ms KS2 who talked me through the Parental Engagement Action Plan they had put together based on the School Development Plan and an action plan template provided in Pathways. They said that the action plan had to be checked through with Mrs Magpie before distribution to other staff.

Later that day, I was sitting with Mrs Magpie as she described the progress that had been made on the Parental Engagement Pathway (that was being managed by Ms KS1 and Ms KS2). She looked down the AP that they had put together, and compared it with the School Development Plan (the more toplevel/strategic of the two plans):

"We do a progress report every term, [based on] the [School Development Plan] SDP - which is shared with

parents... [Mrs Magpie reads off the Action Plan] "Attendance has to be improved with Pupil Premium children."”,

I asked how Mrs Magpie might describe current attendance of Pupil Premium children.

She replied raising her voice slightly:

'It's actually bigher than the whole school... Teachers have (middle class) assumptions about Pupil Premium children, assuming they won't come to school. The whole point of parental engagement is to improve attendance, especially for Early Years, but it's whole school attendance.”[Mrs Magpie_MS_Nov-2015]

Had it seemed to Mrs Magpie that I had made the same 'middle class' assumption by asking that question? It was difficult to tell but I quickly realised that I had wandered into a slightly different line of enquiry to the one my question had prepared me for. After talking things over a bit more, I understood that Mrs Magpie and her Pathways team were grappling with an issue at multiple levels: 
- attendance - but not the same attendance that was being planned for in the Action Plan;

- assumptions being made about pupils, their backgrounds and academic expectations - which emerged as the key issue from either the question I asked or how I asked it (or indeed a completely unrelated reason); and

- needing to improve relationships with parents - but first needing to understand which parents to target.

This encounter was a brief but valuable lesson in how the framing of a question matters, particularly in terms of how it is interpreted and understood. It also illustrated - consistent with the DASI - how pupil attainment is influenced by an intersection of teacher, student, school and system level factors, and the need to carefully investigate factors within the same level as well as across multiple levels (Creemers and Kyriakides, 2012). The topic of moral judgements and values (phronesis) had arisen - what looked like a generic line based on what might have been termed 'common sense knowledge' in an action plan appeared loaded with several assumptions, possibly remaining unknown until quick, reflexive moments like these. Mrs Magpie was saying that assumptions were being made on certain groups like Pupil Premium children, I wondered about the challenge this presented if one was using research evidence which highlights the differences in the home learning environment and access to enrichment activities children might have based on their socioeconomic status. How does one know when to use evidence to pre-empt issues and when to hold back and watch what happens? This provided me with feedback about the dangers of lumping together all 'hard to reach parents'. I also became mindful of the structure provided by Mrs Magpie - creating "hospitable conditions" which both enabled and in some ways, constrained, sometimes guided, the practices of her two early career teachers, now acting essentially as middle leaders (Grootenboer, Edwards-Groves and Ronnerman, 2016: 518).

\section{Dealing with 'the issue'}

A questionnaire was sent out to parents asking for their views on how to improve communications with them a few weeks after the interview above. The results were reported as revealing but unsurprising:

- Homework was raised as a "big thing" according to Ms KS1:

'There's not much scope for parents to engage. They wanted more work to do with them [their children]. We're thinking of projects, sheets of instructions... We're doing 'councils' this term, we could have a model council by the end. Parents who responded are the parents who always respond. We've gone around the teachers and asked them which parents are unwilling to engage, and created a list. Next step is to share it with staff and ask who's worked with these families. From the questionnaires, we have a list of parents who said they do want to help. So, those who've said they want to help with science, we'll give those names to the science coordinators." [Ms KS1_MS_Jan-2016]

- $\quad$ After learning about parents' views on homework, Ms KS1 agreed: 
"Homework - after speaking to teachers, it's more of an after-thought. The other thing that came up was not being communicated to enough. It's quite hard. We have newsletters every short term (six times a year). Telling parents what topics are being covered, maths, English, science. They want a much more detailed description. Do you give them each learning objective? We don't want to overload teachers. Whether parents will do anything with the information. We are going to do an interim questionnaire online and hopefully get a bigger response." [Ms KS1_MS_200116]

Here was a new layer to the problem - weighing up what are 'effective communications' to parents who seem to have somewhat contradictory needs - possibly wanting more information but not always acknowledging the information they did receive. Also, what are 'effective communications' that do not overload teachers unnecessarily with extra tasks - churning out information that might be verging on too much. This led us to wonder if by default schools' strategies should be planned on the principle that not all the decisions people (in this case parents) make are necessarily always 'rational'. Parents are busy people too. The other reason could have been that the school wanted parents to engage but mostly on their terms, which is equally understandable from teachers' workload point of view. This problem was becoming more complex.

\section{More information, targeted action}

It was decided that a workshop for parents would be held in March (a 'Stay and Learn' lesson demonstration). Ms KS1 and Ms KS2 were discussing with Mrs Magpie proposed plans to engage parents in preparation for a staff meeting that afternoon:

“We are giving names of families to subject coordinators to reach out to.” [Ms KS2_MS_Jan-2016] In response:

"Good idea, we can have a competition to see who can get the highest number of parents in for the workshop in March.”[Mrs Magpie_MS_Jan-2016]

In February, it transpired that (some) parents may not have been keeping up with school events including those quite close to home:

"Parents don't read the newsletter. I just found out a dinner lady who has a child here - she didn't know an event was happening - Monday's Stay and Learn [in March]. We are making personal invitations!" [Mrs Magpie_MS_Feb-2016]

Towards engaging with the assumptions of the DASI framework

Mrs Magpie and her team, without necessarily being aware of the DASI, seemed to be promoting the design of their school improvement initiatives based on educational research evidence sourced partially from Pathways, and The Key (2018). Mrs Magpie seemed to consider the different factors and dimensions of school effectiveness from the perspective of different stakeholders in Magpie School, in 
supporting the collection of data from pupils, parents and teachers on the school's functioning. Every time we met, Mrs Magpie and Ms KS1 and KS2 appeared to have moved a previously identified school improvement strategy a bit further with a new survey or trialling a new approach with their parents, and then eliciting information from the people involved about how particular components of the strategy might be improved. Most of all, it came across fairly strongly that Mrs Magpie was trying to develop a professional learning and development community among the teachers who were managing Pathways and their colleagues, including teaching assistants, in engaging with educational research and taking different approaches to implement action and evaluation. The team also really seemed to engage with me and Pathways as a kind of Advisory and Research Team composite and participate in conversations about school improvement research - for example when I spoke to Mrs Magpie about work by Timperley et al (2007) around staff meetings, and their focus on pupil attainment and progress leading to better outcomes.

\section{Level 4: Participants' use of new knowledge and skill (Guskey, 2002)}

I asked Mrs Magpie, Ms KS1 and Ms KS2 what they were making of Pathways so far. Staff personalities and attitudes plus external research support/mediation were raised:

'What pulls this together is two people who are really keen, with an action plan! [Mrs Magpie smiled at the two teachers.]

And great having Susie, we can't just say we haven't done anything since the last time you came. It's someone who leads it from the outside.” [Mrs Magpie_MS_Feb-2016]

Trialling different modes of communication was brought up too:

'Talking with parents on a Wed - learning that they don't read the newsletter - faster than a questionnaire! Sitting with the children for a few minutes and asking them things helps.” [Mrs Magpie_MS_Feb-2016]

This nudged forth the topic of "Inquiry habit of mind" - as another interpretation of events described so far. Magpie, and indeed other schools, in trying to fill the void left by the disappearance of local authority support and free structured resources previously supplied by the DfE post-2010, could be viewed as adopting a precarious form of 'picking and mixing'. Schools are faced with sourcing, interpreting, choosing, communicating and applying a variety of research and other evidence from different providers and decide 'what has worked'. The connotation of 'picking and mixing' seemed to be negative when mentioned at OUP Pathways steering group meetings, for example. However, if school leaders are meant to have "well-developed inquiry habits of mind" (Earl and Katz, 2006: 108), are exploring, picking and incorporating (and discarding) information not part of that development? How does one keep inquiry habits' in some parts of leadership and switch it off or tone it down for the rest? Perhaps this is a subject that should be explored more in research - the degrees to which certain skills are applied at different 
times during the school improvement journey, and the consequences of these actions, as opposed to just the basic application of those skills. It seems a never-ending paradox - if you give professionals the tools to ask questions of their data, their teams, and help to develop their skills to constantly inquire and question, and challenge assumptions, tacit knowledge and expectations, will they not eventually question the system that may have supported them to develop those skills too? How does one 'trust' a brand/name/system based on previous results but still question its methods, and does this form part of the leaders' duty to continually challenge complacency?

\section{From broader theory to specific practice?}

The next theme that seemed to be emerging was how Pathways (and other school improvement tools, and the process of discussing the matter at all) were being used to possibly ground strategies more in immediate 'reality' and translate those strategies into a sequence of recognisable steps. This was consistent with how the DASI encourages practitioners to identify specific conditions that may influence improvement efforts, and make explicit links with pupils' attainment. Ms KS2 described the idea of the "Stay and Learn" planned for March:

"Parents are going to drop their children off and meet [Mrs Magpie] for a general discussion about school values.

That gives parents a chance to influence our school values for next year. (That's in the action plan. [Mrs Magpie] is ticking that off for us!)

The parents will come to the classroom and watch a normal maths lesson. We thought what parents really struggle with - when we do open mornings - is it's quite gimmicky. 'Here's a carousel of activities that we don't actually do.' I mean you do, but not as an everyday practice. So we thought it would be good for them to see an actual maths lesson. This is the first time we're doing it in the morning, it's usually in the afternoon. We get a good turnout in the afternoon, but we thought if parents are dropping their children off in the morning anyway... We found that if we arranged things for when they picked their children up in the afternoon, they would come, so like this there are no excuses.” [Ms KS2_MS_Feb-2016]

The opportunity to tangibly share the workload of a project in combination with a supportive senior leadership team and school ethos were also raised in relation to the two teachers working together on Pathways:

"[Mrs Magpie] will give us time out of our working day to work on this. Having two of us working on itespecially this kind of Pathway, it's made for two people! ([Ms KS2 interjects:] Bouncing ideas off, getting each other started early in the morning, reminding each other what the next steps are etc.!) Because we're in KS1 and KS2. Might have been too big a job on your own. Also, I don't see the KS2 teachers very often because you have different break. times. It would take a lot more time outside of school hours. Now we just have quick PP $A$ [Planning, Preparation and Assessment] time to talk to each other.”[Ms KS1_MS_Feb-2016] 
A report by CUREE on how teachers use research evidence states that experiences which help teachers progress in their professional learning and practices include experimentation, collaboration with external parties, taking appropriate risks and "analysing and critically reflecting on the evidence and on practice" (CUREE, 2012: 12). The idea of experimentation links well with the potential affordances of Pathways as a space for professional learning - for example in Mrs Magpie's approach of mediating teachers' autonomy to improve the school's engagement with parents. Returning to our original argument about Pathways artefacts potentially supporting practitioners' efforts towards collective school improvement, Bell et. al. (2010: 40) advance that:

When research engagement involves more than one practitioner, application of research to existing standards and contexts is richer.... As the number of teachers expands, so does the number of working contexts and the relevance of working standards. In these situations it becomes more important to identify key principles and the underlying theory in order to adapt research findings from elsewhere or from micro-inquiry safely.

This reveals another characteristic of the collaborative but again precarious nature of information ecologies within and surrounding schools in this age of digital technologies - the idea of "produsage". Practitioners not only consume resources but contribute to their production with their own experiences and comment - not in the traditional sense of production but "produsage":

... [A]n iterative, evolutionary process aimed at the gradual improvement of the community's shared content. Such gradual, probabilistic processes do not ensure against temporary reductions in quality as poor-quality contributions are made by individual produsers, but over time the shared community resource is expected to improve in quality as long as such negative contributions are outweighed by the impact of a larger number of positive contributions. (Bruns, 2008: 27)

To ensure that outputs continue to be trustworthy and usable, Bruns (2008: 27) argues that negative contributions are first identified and neutralised, and that "produsage" communities therefore rely on a finely-balanced combination of community- and technology-based 'mediation'. As with the use of Pathways, and the "produsage" of audit and strategic plans and questionnaires that are downloaded from 'the source' and added to, amended, improved - another kind of mediation emerges that is used to maintain an acceptable degree of quality and usability across users. Environments like Pathways, and those that go even further by offering a space for practitioners to share and "produse" externally - offer, - even with the most basic use of word processing software - a "development history" of content and the facility to access the contributions of individual participants (via the use of 'track changes' and 'comments'), as well as means of rolling back changes to a point preceding negative or inappropriate contributions (Bruns, 2008: 27). We argue that online platforms that house customisable tools provide structured spaces in which to 'safely' "produse" and meet around:

"Such outcomes, produced through social processes, take on some of the aspects of those processes themselves; they resemble cultural artefacts more than commercial products." (Bruns, 2008: 27) 
Parallels can be drawn with Pathways tools, and the original exploration of this study into 'school improvement in context'. Yet, if an action plan is now deemed an unfinished artefact, this begs the question, so what? Well, this helps to make sense of what school improvement is or can be: a joint collaborative activity, with different contributions from different levels - rendering documents that are almost never 'complete'. The idea that Pathways provides a platform in which to hold these 'discussions' and "produse" in turn exposes one possible reason that some schools take to Pathways while others do not. Creating and working in a space where "produsage" is commonplace and in a way, respected, may be a characteristic that is developed within certain types of information ecologies. Some schools, organisations or teams may already have the capacity to work this way, but perhaps one in which the process of recording and rewriting is more alien quickly renders this kind of space irrelevant.

This leads to the next question concerning possible inhibitors and enablers in this space.

\section{DBR episode}

The 'art' (techne), 'science' (episteme) and value judgements (phronesis) of knowing when to question, trust (or do something in between) depending on the subject matter can be extended to different facets of school life, for example:

- Magpie's scepticism of Ofsted, as articulated by Mrs Magpie:

"You can be outstanding one day, and the next, because you take in results from statemented children (as you should), you could become a failing school. Ridiculous.”[Mrs Magpie_MS_May-2016]

- the insistence of Mrs Magpie that attendance at parents' meetings must be 100 percent in the school's drive to maximise parental engagement. To achieve this, Magpie's teachers are available at different times during the school day, and the children are "held onto" so that each parent has to come in and "find their child". The headteacher admits, otherwise, it is difficult to "get them in" to participate - for example, at parent workshops, a recent one on P4C (Philosophy for Children) attracted only 40 out of the school's 460 children's parents.

- an 'enforced democracy' in which staff were encouraged to fill in Pathways questionnaires and give their views:

"[We] [g]ave questionnaires to staff and they couldn't leave the meeting without completing it. Dependent on rank in school or how you are with people generally - whether you get a good response.” [Mrs Magpie_MS_Aug2015]

- the importance of which kinds of 'personalities' are involved, but also what a particular strategy is about - exemplified by Mrs Magpie's comment that if their Deputy Headteacher says something, it is not taken on board, but another ['Named teacher'] received a different response [to Pathways questionnaires] because it was the National Curriculum", and that it was that [Named teacher']; and 
- the need to illustrate what an action is for - along the lines of Guskey's (2002) alternative model of teacher change - before teachers buy into it:

"E.g. Iris Connect ${ }^{7}$ - you need to show teachers how it can help them before they'll use it." [Mrs

Magpie_MS_Jan-2016]

The belief that Pathways is 'good for you' - reinforced at steering group meetings and even within Magpie School may play out similarly to the outcomes of 'enforced democracy'. This, along with the complexities in determining the 'right' combination of episteme, techne and phronesis was illustrated by a short but telling scene that unfolded during a staff meeting at Magpie. The meeting's focus was how to increase parental engagement and was structured using various Pathways resources. As before, Ms KS1 and Ms KS2 were managing the Pathway with their headteacher Mrs Magpie.

The staff meeting began in a classroom with a short PowerPoint presentation delivered by Ms KS1 and Ms KS2, using a Pathways template populated with Ofsted's aims and expectations regarding parental engagement. Most teachers were present, as were teaching assistants. I was handed the revised AP that had been changed after a discussion with Mrs Magpie.

Mrs Magpie left the room for a few minutes and when she came back (while the discussion activity was taking place) she decided not to sit at the 'head' of the table but moved round to the side of the table. The discussion activity took the form of a "carousel" - where groups of teachers sat at three different tables. Each group was tasked with writing on some sugar paper on the topic of parental engagement and after a few minutes, each paper moved to the next desk until all tables had filled out all three pieces of paper. There were about seven staff members at each table. Ms KS2 instructed:

"We have created an action plan for parental engagement exploring three priority areas.

1. Ensuring parents are involved in creating the school vision.

2. To develop staff skills in working in partnership with parents

3. Improve the ways we communicate with parents.

We have written those key areas and our plans on how to implement them on sugar paper. Can you tell us what you think and give us ideas on what else we can do?” [Ms KS2_MS_Nov-2015]

After the carousel activity, the meeting presentation was resumed. Ms KS1 who was in charge of managing the design of the new school website presented the new layout on screen. Proceedings continued with a video showing ways to increase parental engagement. The group clapped when the video was stopped.

\footnotetext{
${ }^{17}$ A video-based professional learning platform [http://www.irisconnect.co.uk/products-and-services/ourlesson-observation-platform/]
} 
Ms KS1 and Ms KS2 thanked the audience and went on to discuss how to restructure and narrow down a questionnaire for parents (also from Pathways). The aim they said was to get early years' parents in to improve attendance:

"We need to have a reason for why we want parents to come in. Every workshop we have, you say 'can we have it 2.15 to 3.15...' We need to make it more convenient for parents. The Maths Trail worked for parents, [we got about] 40-50 parents. [Planning, Preparation and Assessment] PPA meetings: we need to decide what works with parents and why we engage them. The whole purpose is to improve attendance. Talking to parents, keeping them coming in etc. - that is the purpose.” [Ms KS2_MS_Nov-2015]

One teacher suggested that instead of the title on the front of the questionnaire that read "Background demographic questionnaire", it said something like 'Background Information' to make it more accessible. Ideas on the sugar paper were reviewed, one was a 'craft afternoon' - getting children to write invitations to school.

Ms KS1 suggested that a craft afternoon must be a whole-school event.

One teacher asked if it would be the whole afternoon. Ms KS1 and Ms KS2 answered 'yes'. Ms KS2 went on to say:

"Ifyou don't want parents coming in, you have to say why not. [tries to get more ideas from teachers for parents to come in.] Making Christmas decorations? Monday the 23rd, getting parents to come in. We have to be very organised with what you want to do with parents."

Several features seemed apparent at this meeting - linking back to extant literature on collaborative inquiry (Jackson and Street, 2005: 41) and "produsage" (Bruns, 2008) detailed earlier.

- Ms KS1 and Ms KS2 presented the school aims and priorities - taking the current school context as the starting point;

- There seemed to be problematising of the day-to-day work (not making assumptions about what is going on, but questioning what is taken for granted):

"[B]ecause people often lack shared histories and meanings (especially when they are in differing groups or organisations), information must be recontextualised to reuse experience or knowledge. Systems often assume a shared understanding of information." (Ackerman, 2010: 68);

- Notions of building out from what has gone before and what is already known were observed, along with opportunities to create visible and tangible communication exchanges and share information that potentially enable learning (e.g. situated learning or learning in a community of practice);

- Both early career teachers appeared to develop more experience of how to present different types of information to their colleagues, some of whom may have been teaching for many years; and estimate the implications of showing a particular training or development video that was based 
on research evidence of best practice. When asked how come the video had been stopped before it finished, Ms KS2 responded:

"Sometimes we have to be careful with the teachers here, they might take offence, especially with young teachers doing it. We've got quite a few teachers who've been here for a long time. They're harder to persuade. Not that they won't take things on but we have to pitch it really carefully. We thought the general mood was... so we thought we should stop.”[Ms KS2_MS_Feb-2016]

This presented another 'DBR moment' represented by the following exchange between me and Ms KS1 and Ms KS2.

Researcher: "How did you gauge this?" [i.e. knowing when to stop the video]

Ms KS2: "We see how things backfire in staff meetings all the time. When quiet descends..."

Researcher: "How do you think that video could be improved?"

Ms KS2: "Keeping them really short. That video was 5 minutes long. Keeping it to the 2 to 3-minute range is most helpful for the attention span of the staff. Concise points. And more ideas rather than background. Less of what not to do. Good practice ideas, how other schools have done it. Teaching, you've got to think, why reinvent the wheel all the time." [MS_Feb-2016]

The conversation continued. I wondered about Pathways being used as a space to run ideas past colleagues at staff meetings, and asked what other ideas had been fielded since the staff meeting in November 2015:

"We ran a few ideas that were shot down immediately. E.g. [classroom teachers] going outside in the morning to meet parents in the playground - they refused. Normally only the headteacher or deputy [does that]. We thought we could get a rota going. They said no.” [Ms KS2_MS_Feb-2016]

I suggested that many other schools do it and I was surprised that this idea was "shot down". The DBR moment continued as I tried to untangle how the idea was shot down, and by whom.

Researcher: "Why do you think going outside to see parents in the morning was not well received, in this particular school context?"

Ms KS2: “Because it's their time to set up. Some days can be very hectic. There's always something to prep for.

[Mrs Magbie] wasn't in that particular staff meeting where we discussed this. We generally speak. to [Mrs Magbie] or SLT before we go to the rest of the staff."

Ms KS1: "SLT didn't like it. They didn't want to overburden us. I didn't think it was a big deal. By that point, 10 minutes before the lesson you'd think you'd be prepared already."

I pursued the topic again when Mrs Magpie joined our conversation later. We were talking about ways to encourage parents to read the school newsletter: 
'Parents say they want more information, but they don't read it... Can't send it with children to take it back, parents haven't got a printer, so we can't do that [email]. Only way is to have a secret somewhere in the newsletter that the children have to find, a little bird etc., spot the owl - have a competition where they have to look at the newsletter in order to answer the question. Average parents don't read the newsletter. Even Teaching Assistants who are parents don't read it. Until you can hone in on people who should know... we tried to have parent champion, that didn't work, people are busy. Class champion, TA champion, I don't know. something where they go out to meet parents at the end of the day." [Mrs Magpie_MS_Feb-2016]

Ms KS1: "We were talking about this before - teachers going to out to meet parents in the morning... Loads of schools do that."

Mrs Magpie: 'I went to one part of the school and it was 10 to 9, it was freezing, [I said] could you let them in? It's about going to greet the parents; 25 to 9 you should be ready. You could take turns. Just saying hello."

Ms KS1: "So many people commented on you [Mrs Magpie] being out there, it was positive."

Mrs Magpie: "If we all did it... talking about 5 minutes..."

Ms KS1: "But nobody in SLT liked it."

Mrs Magpie: "Could it not be at 20 to 9, duty day... open the door, couple of minutes to let people in. That's a really clever one, isn't it? I think SLT thought the staff wouldn't like it, it's not they didn't like it. So, let's just go for it." [Ms KS1 and Ms KS2 agreed to propose this.]

Mrs Magpie: "Good, so it's not muggins saying it. Max of 5 minutes (good psychology of putting it). Opening the door to let them in. That way, if it's raining, you'll realise they're soaking. No teacher is going to want to stay out in the rain, it solves that problem, opening the doors. Secondaries do that. [St. Robin's School] does it. They'll hate that."

Researcher: "Why would they hate that?"

Mrs Magpie: "It's a nice school up the road, if they can do it, we can do it."

This example of a 'DBR moment' links well with features highlighted by Jackson and Street (2005: 35) where collaborative inquiry is recognised as a "particular type of school-based research" that explores aspects of practice with an agreed focus, and practitioners "drawing on the current knowledge and research base and working with and integrating that with their own knowledge and experience; and practitioners often working with an external colleague from higher education who supports the inquiry process". The potential affordances of a space such as Pathways and its provision of educational research evidence may offer opportunities for practitioners to participate in more a structured form of collaborative inquiry, which in turn could support, amongst other things. a readiness to engage with, and to learn from, educational theory and research and a capacity for knowledge-sharing and to act on what has been learnt in a school (Jackson and Street, 2005: 56). The authors go on to suggest that collaborative inquiry helps schools to develop from "learning organisations" to become "professional learning communities" (Jackson and Street, 2005: 57). Mitchell and Sackney (2000: 6) explain the differences between the two terms: 
In a learning organisation, the fundamental values and cultural beliefs are most likely to be defined by the organisational elite, whereas in a learning community, they will be defined by the members of the community in negotiation with one another.

The definition of a 'learning community' is given as:

[A] group of people who take an active, reflective, collaborative, learning-oriented and growth promoting approach towards the mysteries, problems and perplexities of teaching and learning. (Mitchell and Sackney, 2009: 9)

These features closely resemble the collective and shared professional aspects of "produsage" where practitioners consume as well as contribute to the production of resources with their own experiences and views (Bruns, 2008). The collaborative efforts and focus may not always translate to the whole organisation or team necessarily 'knowing' that Pathways is being used but the broad aims seem clearer to key users with the support of senior leadership. Ms KS1 remarked on the new approach to parental engagement in Magpie School that permeated discussions across the school and curriculum, e.g. in matters related to homework, maths, spelling and so on:

"Because there is a role for parental engagement, a focus, more people say if something is being organised, ob we must invite the parents... it's part of everybody's professional journey." [Ms KS1_MS_Feb-2016]

\section{Concluding remarks}

We have illustrated in detail one case study out of the five schools whose school improvement journeys were followed over the two years of the research project. This case highlights the use of multiple methods to collect and understand different facets of practitioners' articulations of improvement practice including interviews, observations and documentary analysis, and how they engaged with the Pathways online resource. The DBR approach was applied in order to unpick in more depth, practitioners' perceptions of their actions, behaviours and reasoning behind how they used and adapted materials to meet both the school's improvement and their own professional development needs. Pathways and other tools like it could potentially be seen as a platform to conduct and understand research, consider data, information and knowledge in different forms (episteme, techne and phronesis), apply evidence to practice, or at least question (previously) firmly held beliefs and consider other perspectives. The quality and utility of what was "prodused" seemed to depend on the type of leadership support provided, the users' and "produsers" levels of interest and commitment, and the characteristics of the interactions that took place between different practitioner groups. Not all strategies might have made it through to implementation but starting points in exemplar action plans and PowerPoint presentations were provided in Pathways. Magpie's use of Pathways featured teachers cooperating to form "learning communities" (Mitchell and Sackney, 2009) and relationships that promoted collaborative inquiry with a Higher Education partner (Jackson and Street, 2005) - attempting to draw on an existing research evidence base (interspersed with practice) and integrate this with 'live' every day practice (also itself interspersed with research evidence). 
Pathways and similar online tools appeared to act as vessels for a kind of "conversational rationality" (Alvesson and Karreman, 2011), a process through which practice and knowledge was developed, discussed and exchanged - a new technologies extension of "supportive school improvement" (Jackson and Street, 2005: 57).

The first research question asked, "what are the views and perceptions of practitioners in their use of Pathways around the functionality of the platform and its tools?”. Consistent with Guskey's (2002) framework for CPD evaluation, responses to Pathways by practitioners appeared to be shaped by each school's professional and improvement context, where some responded more collectively to using Pathways while others approached the platform more for individual extrinsic interests. School leaders and teachers being able to project, plan and coordinate their improvement efforts with the use of Pathways tools also seemed more willing to engage and experiment with new, more unfamiliar resources. Different responses by schools' leadership seemed to provide particular affordances for other staff members to engage with Pathways for improvement and professional development purposes. The second research question asked, "what role does practitioners' use of Pathways (and other related resources) play in supporting individual schools' improvement journeys and approaches and practitioners' professional development experiences?”. In line with the DASI, certain 'hospitable conditions' that supported the use of Pathways included supportive leadership, being able to make strong links between the tools and guidance in Pathways and teaching practice (via both on- and offline communication), coordinated improvement efforts, commitment to 'action inquiry', shared professional practice and recognition and reward. Elements of professional learning for practitioners, particularly early career teachers and those with a specific development task emerged during the study - which supported the idea of how Pathways and other similar resources might have the potential to mediate practitioners' autonomy during efforts to enact school improvement strategies. The findings reveal that Pathways seemed to additionally have the potential to support practices in schools associated with improving the capacity for leadership and improvement - for example, with how practitioners engaged with and 'prodused' a range of tools, tasks, routines and artefacts in moving through the Pathways four-step system.

While one of the limitations of the wider study is that we have focussed on a smaller number of school cases (five in total, and the OUP as a separate case study), the research project as a whole and the illustrative case study featured here have sought to provide depth rather than breadth in understanding practitioners' views and perceptions of Pathways, and engagement in different schools' improvement journeys. The nexus of two fields that are usually studied separately is explored here: school improvement and its links with how knowledge is developed, managed and mediated; and practitioners' use of digital technologies for their own learning and development. The Pathways study's unique contribution to the fields of educational effectiveness and improvement and educational online technologies lies in its innovative application of a DBR framework to study primary school improvement processes and 
journeys, and how these might be influenced by the development of an online technology platform for teachers that aims to extend knowledge and develop their capacities to engage in improvement practice.

\section{References}

Ackerman, M. S. (2010) The intellectual challenge of CSCW: the gap between social requirements and technical feasibility. In: H. Donelan, K. Kear and M. Ramage (eds.) Online Communication and Collaboration, (Oxford: Routledge), 66-72.

Ainscow, M. \& Hopkins, D. (1992) Aboard the "Moving School". Educational Leadership: Improving School Quality, 50(3), 79-81.

Aitkin, C. \& Spellman, L. (2012) Improving the quality of teaching: Opinion piece. (Nottingham: National College for School Leadership.)

Alvesson, M. \& Kärreman, A. (2011) Qualitative Research and Theory Development: Mystery as Method. (London: Sage.)

Argyris, C., \& Schön, D. (1978) Organisational learning: A theory of action perspective. Reading, MA: Addison Wesley.

Bain, A. \& Swan, G. (2011) Technology enhanced feedback tools as a knowledge management mechanism for supporting professional growth and school reform. Educational Technology Research and Development, 59(5), 673-685.

Barth, R. (1990) Improving Schools from Within. (San Francisco: Jossey Bass.)

Bassey, M. (1999) Case Study Research in Educational Settings. (Buckingham: Open University.)

Bell, M., Cordingley, P., Isham, C. \& Davis, R. (2010) Report of Professional Practitioner Use of Research Review: Practitioner Engagement in and/ or with Research. (Coventry: CUREE, GTCE, LSIS and NTRP.)

Blau, I. \& Presser, O. (2013) E-Leadership of school principals: Increasing school effectiveness by a school data management system. British Journal of Educational Technology, 44(6), 1000-1011.

Bruns, A. (2008) Blogs, Wikipedia, Second Life, and Beyond: From Production to Produsage, (New York: Peter Lang Publishing.)

Bubb, S. \& Earley, P. \& Ahtaridou, E. \& Jones, J. \& Taylor, C. (2007) The self-evaluation form: Is the SEF aiding school improvement? Management in Education, 21(3), 32-37.

Chapman, C. \& Sammons, P. (2013) School Self-evaluation for School Improvement: What works and why? Project Report. (CfBT Education Trust, Reading.)

Collins, A., Joseph, D. \& Bielaczyc, K. (2004) Design Research: Theoretical and Methodological Issues. Journal of the Learning Sciences, 13(1), 15-42.

Creemers, B., \& Kyriakides, L. (2008). A theoretical based approach to educational improvement: Establishing links between educational effectiveness research and school improvement (pp. 1-25). Available online at: http://www.rug.nl/staff/b.p.m.creemers/a theoretical based approach to educational improve ment.pdf (accessed 1 April 2018) 
Creemers, B. P. M., \& Kyriakides, L. (2009) Situational effects of the school factors included in the dynamic model of educational effectiveness. South African Journal of Education, 29(3), 293-315.

Creemers, B. P. M., \& Kyriakides, L. (2010a) Explaining stability and changes in school effectiveness by looking at changes in the functioning of school factors. School Effectiveness and School Improvement, 21(4), 409-427.

Creemers, B. P. M., \& Kyriakides, L. (2010b) Using the dynamic model to develop an evidence based and theory-driven approach to school improvement. Irish Educational Studies, 29(1), 5-23.

Creemers, B. P. M. \& Kyriakides, L. (2012) Improving Quality in Education: Dynamic Approaches to School Improvement. (Oxford/Canada: Routledge.)

Creemers, B. P. M. \& Kyriakides, L. (2015) Developing, testing, and using theoretical models for promoting quality in education. School Effectiveness and School Improvement, 26(1), 102-119.

Creemers, B. P. M., Stoll, L. \& Reezigt, G. (2007) Effective School Improvement - Ingredients for Success: The Results of an International Comparative Study of Best Practice Case Studies. In: T. Townsend (Ed.) International Handbook of School Effectiveness and Improvement, (The Netherlands: Springer), 825-838.

CUREE - Centre for the Use of Research Evidence in Education (2012) Understanding What Enables High Quality Professional Learning: A report on the research evidence. (London: Pearson School Improvement.)

Day, C., Sammons, P., Leithwood, K., Hopkins, D., Gu, Q., Brown, E. \& Ahtaridou, E. (2011) School Leadership and Student Outcomes: Linking with Learning. (Maidenhead: McGraw Hill Open University Press.)

DfE - Department for Education (2013a) 2014 National Curriculum. Available online at: http://www.education.gov.uk/schools/teachingandlearning/curriculum/nationalcurriculum2014/ (accessed 7 November 2013)

DfE (2013b) Teachers' pay: changes since September 2013. Available online at: https://www.gov.uk/government/news/teachers-pay-changes-since-september-2013 (accessed 31 December 2016)

DfE (2014) National Curriculum [online] Available online at: https://www.gov.uk/government/collections/national-curriculum (accessed 1 April 2018)

DfE (2016a) Schools, Pupils and their Characteristics: January 2016 - National Tables. Available online at: https://www.gov.uk/government/uploads/system/uploads/attachment data/file/532038/SFR20 2016 National Tables.xlsx (accessed 31 December 2016)

DfE (2016b) Statistics at DfE. Available online at: https://www.gov.uk/government/organisations/department-for-education/about/statistics (accessed 31 December 2016)

Doherty, C. (2015) Being a magpie teacher. Available online at: http://www.innovatemyschool.com/ideas/being-a-magpie-teacher (accessed 1 April 2018)

Earl, L. M. \& Katz, S. (2006) Leading Schools in a Data-Rich World: Harnessing Data for School Improvement. (London: Sage Publications.) 
Flyvbjerg, B. (2004) Five misunderstandings about case-study research. In: C. Seale, G. Gobo, J. F. Gubrium and D. Silverman (Eds.) Qualitative Research Practice, (London: Sage), 390-404.

Greene, J. C., Caracelli, V. J. \& Graham, W. F. (1989). Toward a Conceptual Framework for MixedMethod Evaluation Designs. Educational Evaluation and Policy Analysis, 11(3), 255-274.

Grootenboer, P., Edwards-Groves, C. \& Ronnerman, K. (2016) Leading practice development: voices from the middle. Professional Development in Education, 41(3), 508-526.

Guskey, T. R. (2002) Does It Make a Difference? Evaluating Professional Development. Educational Leadership, 59(6), 45-51.

Hallinger, P. \& Heck, R. H. (2011) Exploring the journey of school improvement: Classifying and analyzing patterns of change in school improvement processes and learning outcomes. School Effectiveness and School Improvement, 22(1), 1-27.

Hargreaves, D. H. (1998) Creative Professionalism: The Role of Teachers in the Knowledge Society. (London: Demos.)

Harris, A. (2001) Contemporary Perspectives on School Effectiveness and School Improvement. In: A. Harris and N. Bennett (Eds.) School Effectiveness and School Improvement: Alternative Perspectives, (London: Continuum), 7-25.

Harris, A. (2002) School Improvement: What's in it for Schools? (New York: RoutledgeFalmer.)

Harris, A. Chapman, C., Muijs, D., Reynolds, D., Campbell, C., Creemers, B. P. M., Earl, L., Kyriakides, L., Munoz, G., Stoll, L., Stringfield, S., van Velzen, B. \& Weinstein, J. (2013) Getting lost in translation? An analysis of the international engagement of practitioners and policy-makers with the educational effectiveness research base. School Leadership \& Management, 33(1), 3-19.

Harris, A., Jamieson, I. \& Russ, J. (1996) School Effectiveness and School Improvement: A Practical Guide. (London: Pitman.)

Hesse-Biber, S. \& Johnson, R. B. (Eds.) (2015) The Oxford Handbook of Multimethod and Mixed Methods Research Inquiry. (USA: Oxford University Press.)

Hoadley (2004) Methodological Alignment in Design-Based Research. Educational Psychologist, 39(4), 203-212.

Hoeben, T. J. G. (Ed.) (1998) Effective school improvement: State of the art Contribution to a Discussion. (Groningen: Institute of Educational Research, University of Groningen.)

Hopkins, D. (1989) Evaluating for School Development. (Milton Keynes: Open University Press.)

Hopkins, D. (1998) Tensions in and Prospects for School Improvement. In: D. Hopkins. (Ed.) International Handbook of Educational Change; Section 4: The Practice and Theory of School Improvement, (The Netherlands: Kluwer Academic Publishers), 1035-1058.

Hopkins, D., Ainscow, M. and West M. (1994) School Improvement in an Era of Change. (London: Cassell.)

Hopkins, D., Harris, A. \& Jackson, D. (1997) Understanding the school's capacity for development: Growth states and strategies. School Leadership and Management, 17(3), 401-412.

Hopkins, D., Harris, A., Stoll, L. \& Mackay, T. (2011) School and System Improvement: State of the Art Review. [Online] In: 24th International Congress of School Effectiveness and School Improvement, Limassol, Cyprus, January 4-7 2011. Available online at: 
http://www.icsei.net/icsei2011/State of the art/State of the art Session_C.pdf (accessed 7 November 2013)

Hopkins, D., Stringfield, S., Harris, H., Stoll, L. \& Mackay, T. (2014) School and system improvement: a narrative state-of-the-art review. School Effectiveness and School Improvement, 25(2), 257-281.

House of Commons Education and Skills Committee (2006) Special Educational Needs: Third Report of Session 2005-06, Volume I, HC 478-I. (London: House of Commons.)

Jackson, D. \& Street, H. (2005) What does collaborative enquiry look like? In: H. Street and J. Temperley (Eds.) Improving Schools through Collaborative Enquiry. (London: Continuum), 41-71.

Katz, S., Sutherland, S. \& Earl, L. (2002) Developing an evaluation habit of mind. The Canadian Journal of Program Evaluation, 17(2), 103-119.

Kyriakides, L. \& Creemers, B. P. M. (2009) The effects of teacher factors on different outcomes: Two studies testing the validity of the dynamic model. Effective Education, 1(1), 61-85.

Kyriakides, L., Archambault, I. \& Janosz, M. (2013) Searching for stages of effective teaching: A study testing the validity of the dynamic model in Canada. Journal of Classroom Interaction, 48(2), 11-24.

Leask, M. \& Younie, S. (2013) National models for continuing professional development: the challenges of twenty-first-century knowledge management, Professional Development in Education, 39(2), 273-287.

Louis, K. S., Toole, J., \& Hargreaves, A. (1999) Rethinking school improvement. In J. Murphy and K. S. Louis (Eds.), Handbook of research on educational administration (2nd ed.), (San Francisco: JosseyBass), 251-276.

Luyten, H., Visscher, A. \& Witziers, B. (2005) School Effectiveness Research: From a review of the criticism to recommendations for further development. School Effectiveness and School Improvement, 16(3), 249-279.

MacGilchrist, B. (2000) Improving self-improvement? Research Papers in Education, 15(3), 325-338.

MacGilchrist, B., Myers, K. \& Reed, J. (2004) The Intelligent School, 2nd ed., (London: Sage.)

Matthews, P. \& Sammons, P. (2004) Improvement through inspection: an evaluation of the impact of Ofsted's work. (London: Ofsted/Institute of Education.)

Matthews, P. \& Sammons, P. (2005) Survival of the weakest: the differential improvement of schools causing concern in England. London Review of Education, 3(2), 159-176.

McKenney, S. \& Reeves, T. C. (2012) Conducting Educational Design Research. (Oxon: Routledge.)

Mitchell, C. \& Sackney, L. (2000) Profound Improvement Building Capacity for a Learning Community. (Lisse, The Netherlands: Swets and Zeitlinger.)

Monk, D. H. (1994). Subject area preparation of secondary mathematics and science teachers and student achievement. Economics of Education Review, 13(2), 125-145.

Mortimore, P. \& MacBeath, J. (2003) School Effectiveness and Improvement: the story so far. In: M. Preedy and R. Glatter (Eds.) Strategic Leadership and School Improvement, (Thousand Oaks, California: Sage), 233-251. 
Mortimore, P., Sammons, P., Stoll, L., Lewis, D. \& Ecob, R. (1988) School matters: The junior years. (Somerset, UK: Open Books.)

Muijs, D., Kyriakides, L, van der Werf, G., Creemers, B., Timperley, H. \& Earl, L. (2014) State of the art - teacher effectiveness and professional learning. School Effectiveness and School Improvement, 25(2), 231-256.

Norman, R. (1994) 'I Did it My Way': some thoughts on autonomy. Journal of Philosophy of Education, 28(1), 25-34.

NUT - National Union of Teachers (2013) School Teachers' Pay: NUT Guidance on TLR Payments for 2013/14. Available online at: https://www.teachers.org.uk/files/nut-guidance-on-tlr-payments2013-14.doc (accessed 31 December 2016)

OUP - Oxford University Press (2016) Homepage. [online] Available online at: http://global.oup.com/?cc $=\mathrm{gb}($ accessed 31 December 2016)

Panayiotou, A., Kyriakides, L., Creemers, B. P. M., McMahon, L., Vanlaar, G., Pfeifer, M., \& Bren, M. (2013) Teacher behavior and student outcomes: Results of a European study. Paper presented at the Annual Meeting of the American Educational Research Association, April-May 2013, (San Francisco, CA.)

Reed, J. \& Street, H. (2002) School self-evaluation: a process to support pupil and teacher learning. In National School Improvement Network. (NSIN) Research Matters 18, (Institute of Education, University of London.)

Reimann, P. (2013) Design-Based Research - Designing as Research. In: R. Luckin, P. Goodyear, B. Grabowski, N. Winters, J. Underwood and S. Puntambekar (Eds.) Handbook of design in educational technology, (New York: Routledge), 44-52.

Reynolds, D., Hopkins, D. \& Stoll, L. (1993) Linking School Effectiveness Knowledge and School Improvement Practice: Towards a Synergy. School Effectiveness and School Improvement, 4(1), 37-58.

Rowland, M. (2015) Guest post: Marc Rowland's 32 Pupil Premium ideas to magpie. Available online at: http://schoolsimprovement.net/guest-post-marc-rowlands-32-pupil-premium-ideas-magpie/ (accessed 31 December 2016)

Sammons, P. (1996) Complexities in the Judgement of School Effectiveness. Educational Research and Evaluation, 2(2), 113-149.

Sammons, P. (2007) School Effectiveness and Equity: Making Connections. (Literature Review; Executive Summary). (Berkshire: CfBT.)

Sammons, P. (2008) Zero tolerance of failure and New Labour approaches to school improvement in England. Oxford Review of Education, 34(6), 651-664.

Sammons, P. (2010) The Contribution of Mixed Methods to Recent Research on Educational Effectiveness, Chapter 27 In A. Tashakkori \& C. Teddlie (Eds.) Handbook of Mixed Methods Research 2nd Edition, (Thousand Oaks, CA.: Sage.), 697-723.

Sammons, P., Davis, S., Day, C. \& Gu, Q. (2014) Using mixed methods to investigate school improvement and the role of leadership: An example of a longitudinal study in England. Journal of Educational Administration, 52(5), 565-589. 
Sammons, P., Hillman, J. \& Mortimore, P. (1995) Key Characteristics of Effective Schools: A review of school effectiveness research. Ofsted. [online] Available online at: http:// files.eric.ed.gov/fulltext/ED389826.pdf (accessed 7 November 2013)

Scheerens, J. \& Bosker, R. (1997) The Foundations of Educational Effectiveness. (Oxford: Elsevier Science.)

Scheerens, J. (2015) Theories on educational effectiveness and ineffectiveness. School Effectiveness and School Improvement, 26(1), 10-31.

Silins, H. \& Mulford, B. (2002) Schools as learning organisations: The case for system, teacher and student learning. Journal of Educational Administration, 40(5), 425-446.

Spector, J. M., \& Edmonds, G. S. (2002) Knowledge management in instructional design. ERIC Digest EDO-IR2002-02. (Syracuse, NY: ERIC Information Technology Clearinghouse.)

Stake, R. E. (2010) Qualitative Research: Studying how things work, (New York, The Guildford Press.)

Teddlie C. \& Reynolds, D. (2000) The International Handbook of School Effectiveness Research. (New York/London: Falmer Press.)

The Key (2018) Welcome to The Key for School Leaders. [online] Available from: https://schoolleaders.thekeysupport.com// [Accessed 3 July 2018]

Timperley, H., Wilson, A., Barrar, H. and Fung, I. (2007) Teacher Professional Learning and Development. Best Evidence Synthesis Iteration. Education. Vol. 33. NZ: University of Auckland/Ministry of Education.

Wagner, J. (1997) The Unavoidable Intervention of Educational Research: A Framework for Reconsidering Researcher-Practitioner Cooperation. Educational Researcher, 26(7), 13-22.

Williams, R. R. (2001) Introduction. In: R. R. Williams. (Ed.) Beyond Liberalism and Communitarianism: Studies in Hegel's Philosophy of Right. (Albany: State University of New York Press), 1-20. 


\section{Tables}

\section{Table 1: Different strategies and phases of school and system level improvement}

At the school level

Five strategies (Hopkins, Ainscow and West, 1994: 43) representing a more "holistic approach"

(Ainscow and Hopkins, 1992) towards school improvement:

- Planning

- Inquiry, reflection and involvement

- Leadership

- Staff development

- Coordination
Towards the 'system' level

Five phases of school (and system) improvement

(Hopkins et al, 2011: 2)

- Understanding the organisational culture of the school

- Research and individual initiatives

- Managing change and emphasis on leadership

- Building capacity for learning

- Towards systemic improvement 
Table 2: Types of support provided by internal and external stakeholders during the school improvement cycle (after Harris, 2002: 57-65)

\begin{tabular}{|c|c|c|}
\hline \multicolumn{2}{|l|}{ Internal } & \multirow{2}{*}{$\begin{array}{l}\text { External } \\
\text { The "external change agent" could be well }\end{array}$} \\
\hline Research supports the idea that school & & \\
\hline improvement should be 'owned' by the & & placed to assist schools in diagnosing \\
\hline individual school, its teachers and students. & & strengths and weaknesses. External \\
\hline The school 'climate' and 'culture' are vital to & $\Rightarrow \diamond$ & support may include other schools, school \\
\hline the successful transformation of attitudes, & & improvement partners (informal and \\
\hline beliefs and values during the school & & formal), educational organisations or a \\
\hline improvement cycle. & & local authority for example. \\
\hline $\begin{array}{l}\text { Teacher professional development is a crucial } \\
\text { contributor to the concept of a 'learning } \\
\text { organisation' }\end{array}$ & $\Rightarrow \diamond$ & $\begin{array}{l}\text { Can provide expertise related to data } \\
\text { analysis and interpretation }\end{array}$ \\
\hline $\begin{array}{l}\text { Teachers should feel able to experiment and } \\
\text { conduct joint enquiry }\end{array}$ & $\Rightarrow \diamond$ & $\begin{array}{l}\text { "Critical friendship" including reflection, } \\
\text { reformulating concepts and challenging } \\
\text { accepted norms }\end{array}$ \\
\hline $\begin{array}{l}\text { Emphasis on 'professionalism', knowledge } \\
\text { and making connections }\end{array}$ & $\Rightarrow \diamond$ & $\begin{array}{l}\text { Training and continuous professional } \\
\text { development }\end{array}$ \\
\hline $\begin{array}{l}\text { Potential for substantial gains when students } \\
\text { become active participants in improvement } \\
\text { cycle, and are able to contribute to the change } \\
\text { process. }\end{array}$ & $\Rightarrow \diamond$ & $\begin{array}{l}\text { Evaluative feedback: providing the means } \\
\text { and tools to support the school } \\
\text { improvement cycle }\end{array}$ \\
\hline Students are a source of 'data' and intelligence; & & \\
\hline $\begin{array}{l}\text { "school improvement groups" made up of } \\
\text { teachers and students may act as a 'catalyst for } \\
\text { change' and develop alternative communities } \\
\text { of practice. }\end{array}$ & $\Rightarrow \diamond$ & $\begin{array}{l}\text { Opportunities for networking, sharing } \\
\text { knowledge and forming alternative learning } \\
\text { communities. }\end{array}$ \\
\hline
\end{tabular}


Table 3: Five levels of CPD evaluation (Guskey, 2002)

\begin{tabular}{|c|c|c|}
\hline Evaluation level & Main measures & Purpose of measure \\
\hline 1 - Participants' reactions & $\begin{array}{l}\text { Initial satisfaction with the } \\
\text { space/experience/provision }\end{array}$ & $\begin{array}{l}\text { To improve programme } \\
\text { design, communication } \\
\text { and delivery }\end{array}$ \\
\hline 2 - Participants' learning & $\begin{array}{l}\text { Newly gained knowledge and } \\
\text { skills }\end{array}$ & $\begin{array}{l}\text { To improve programme } \\
\text { content, organisation and } \\
\text { structure }\end{array}$ \\
\hline $\begin{array}{l}3 \text { - Organisation support and } \\
\text { change }\end{array}$ & $\begin{array}{l}\text { Leadership and organisational } \\
\text { structures that may provide } \\
\text { advocacy, recognition and } \\
\text { facilitation }\end{array}$ & $\begin{array}{l}\text { To chart journey maps of } \\
\text { practitioners' experiences } \\
\text { and potential inform future } \\
\text { change efforts }\end{array}$ \\
\hline $\begin{array}{c}4 \text { - Participants' use of new } \\
\text { knowledge and skills }\end{array}$ & $\begin{array}{l}\text { Strength and quality of } \\
\text { implementation }\end{array}$ & $\begin{array}{l}\text { To improve and document } \\
\text { how a programme was } \\
\text { implemented from } \\
\text { different perspectives }\end{array}$ \\
\hline 5 - Pupil learning outcomes & $\begin{array}{l}\text { Cognitive, affective and } \\
\text { psychomotor }\end{array}$ & $\begin{array}{l}\text { To demonstrate impact of } \\
\text { professional development } \\
\text { and improve the next } \\
\text { iteration of the } \\
\text { programme's design }\end{array}$ \\
\hline
\end{tabular}

